SANDIA REPORT

SAND95-1120 • UC-721

Unlimited Release

Printed November 1995 is

F.

O\&TI

\title{
Case Studies of Sealing Methods and Materials Used in the Salt and Potash Mining Industries
}

\author{
T. J. Eyermann, L. L. Van Sambeek, F. D. Hansen
}

Prepared by

Sandia National Laboratories

Albuquerque, New Mexico 87185 and Livermore, California 94550

for the United States Department of Energy

under Contract DE-AC04-94AL85000

Approved for public retease, distribution is unlimited. 
Issued by Sandia National Laboratories, operated for the United States Department of Energy by Sandia Corporation.

NOTICE: This report was prepared as an account of work sponsored by an agency of the United States Government. Neither the United States Government nor any agency thereof, nor any of their employees, nor any of their contractors, subcontractors, or their employees, makes any warranty, express or implied, or assumes any legal liability or responsibility for the accuracy, completeness, or usefulness of any information, apparatus, product, or process disclosed, or represents that its use would not infringe privately owned rights. Reference herein to any specific commercial product, process, or service by trade name, trademark, manufacturer, or otherwise, does not necessarily constitute or imply its endorsement, recommendation, or favoring by the United States Government, any agency thereof or any of their contractors or subcontractors. The views and opinions expressed herein do not necessarily state or reflect those of the United States Government, any agency thereof or any of their contractors.

Printed in the United States of America. This report has been reproduced directly from the best available copy.

Available to DOE and DOE contractors from

Office of Scientific and Technical Information

PO Box 62

Oak Ridge, TN 37831

Prices available from (615) 576-8401, FTS 626-8401

Available to the public from

National Technical Information Service

US Department of Commerce

5285 Port Royal Rd

Springfield, VA 22161

NTIS price codes

Printed copy: A05

Microfiche copy: A01 
SAND95-1120

Distribution

Unlimited Release

Printed November 1995

Category UC-721

\title{
Case Studies of Sealing Methods and Materials Used in the Salt and Potash Mining Industries
}

\author{
T.J. Eyermann, L.L. Van Sambeek \\ $\mathrm{RE} / \mathrm{SPEC}$ Inc. \\ Rapid City, SD 57709-0725 \\ F.D. Hansen \\ Repository Isolation Systems Department \\ Sandia National Laboratories \\ Albuquerque, NM 87185-5800
}

\begin{abstract}
Sealing methods and materials currently used in salt and potash industries were surveyed to determine if systems analogous to the shaft seal design proposed for the Waste Isolation Pilot Plant (WIPP) exist. Emphasis was first given to concrete and then expanded to include other materials. Representative case studies could provide useful design, construction, and performance information for development of the WIPP shaft seal system design. This report contains a summary of engineering and construction details of various sealing methods used by mining industries for bulkheads and shaft liners. Industrial experience, as determined from site visits and literature reviews, provides few examples of bulkheads built in salt and potash mines for control of water. Sealing experiences representing site-specific conditions often have little engineering design to back up the methods employed and even less quantitative evaluation of seal performance. Cases examined include successes and failures, and both contribute to a database of experiences. Mass salt-saturated concrete placement under ground was accomplished under several varied conditions. Information derived from this database has been used to assess the performance of concrete as a seal material. Concrete appears to be a robust material with successes in several case studies.
\end{abstract}

\section{MASTER}




\section{CONTENTS}

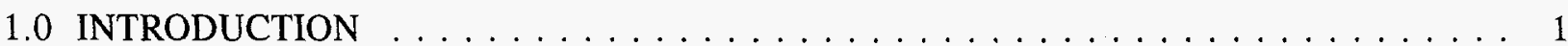

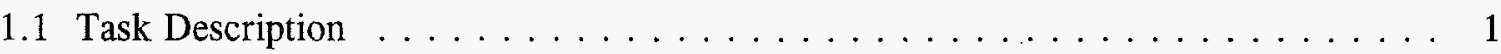

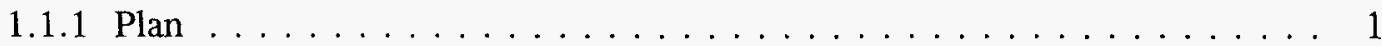

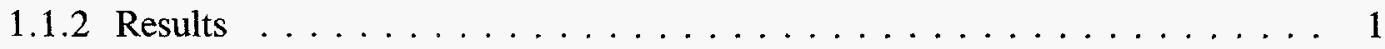

1.2 Waste Isolation Pilot Plant Seals Program . . . . . . . . . . . . . . . 2

1.3 Potential Seal Materials . . . . . . . . . . . . . . . . . . . . . . . . 4

1.3.1 Concrete . . . . . . . . . . . . . . . . . . . . 4

1.3.2 Bentonite and Other Clays . . . . . . . . . . . . . . 4

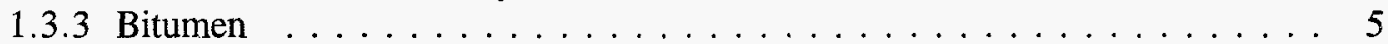

1.3 .4 Grouts $\ldots \ldots \ldots \ldots \ldots \ldots \ldots \ldots \ldots \ldots \ldots$

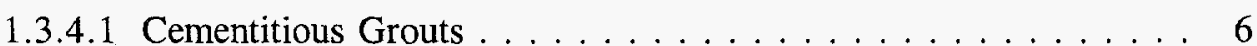

1.3.4.2 Chemical Grouts . . . . . . . . . . . . . . . . 7

1.3.5 Crushed Salt . . . . . . . . . . . . . . . . . . 7

1.3.6 Hydrophilic Seal Material . . . . . . . . . . . . . . 7

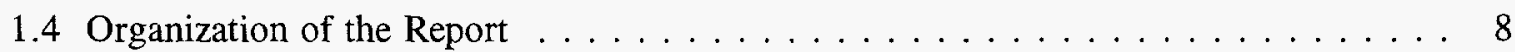

2.0 RESEARCH DESCRIPTION $\ldots \ldots \ldots \ldots \ldots \ldots \ldots \ldots \ldots \ldots$

3.0 POTASH AND SALT MINE UNDERGROUND SEALING $\ldots \ldots \ldots \ldots \ldots \ldots$

3.1 Bulkheads . . . . . . . . . . . . . . . . . . . . . . . . 11

3.1 .1 Weeks Island . . . . . . . . . . . . . . . . . . . . . . . . 12

3.1.1.1 Markel Mine Isolation $\ldots \ldots \ldots \ldots \ldots \ldots \ldots \ldots$

3.1 .1 .2 Oil Isolation Bulkheads . . . . . . . . . . . . . . . . 16

3.1 .1 .3 Wet Drift Bulkhead ..................... 20

3.1 .2 Hope Mine . . . . . . . . . . . . . . . . . . . 22

3.1 .3 Rocanville Potash Mine . . . . . . . . . . . . . . . . . 24

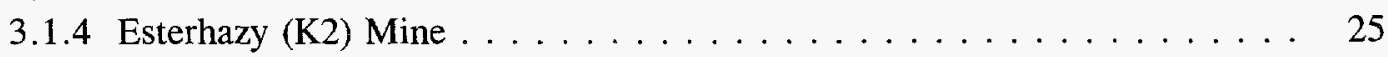

3.1 .5 Wilhelmine-Carlsglück Mine . . . . . . . . . . . . . . . . 27

3.2 Shaft Liners in Salt . . . . . . . . . . . . . . . . . . 27

3.2 .1 Cote Blanche ....................... 30

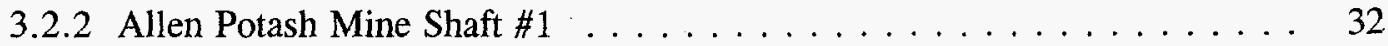

3.2 .3 Erichssegen Shaft . . . . . . . . . . . . . . . . 33

3.2 .4 Cominco Potash Mine \#2 Shaft . . . . . . . . . . . . . . . 33

3.2 .5 Willhelmine-Carlsglück Shafts . . . . . . . . . . . . . . . . 34 


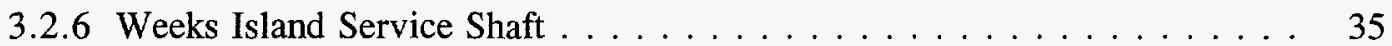

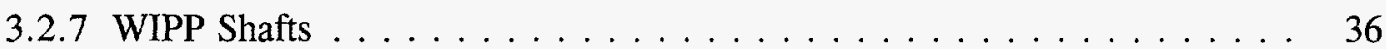

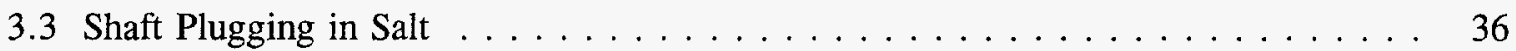

3.3.1 Jefferson Island Sealed Air Shaft $\ldots \ldots \ldots \ldots \ldots \ldots \ldots \ldots$

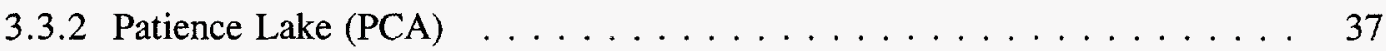

3.3 .3 Retsof Sterling "C" Shaft . . . . . . . . . . . . . . 37

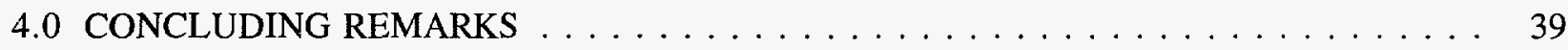

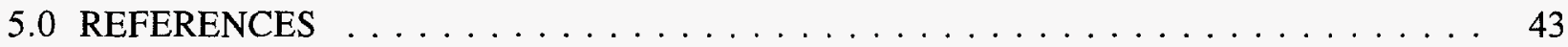

APPENDIX A: CANADIAN MINES FIELD TRIP REPORT $\ldots \ldots \ldots \ldots \ldots \ldots$

Figures

3-1. Schematic Cross Section of Weeks Island SPR Oil Storage Facility (From Jacobs

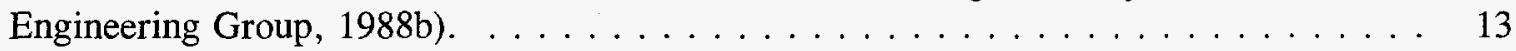

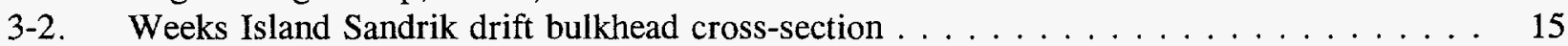

3-3. Conceptual Schematic of SPR Oil Isolation Bulkheads . . . . . . . . . . . . . 17

3-4. Conceptual Plan View of SPR Wet Drift Bulkhead . . . . . . . . . . . . . . 21

3-5. Cross Section of Bulkhead in Hope Mine, Germany (From Fischle and Stöver, 1986) . 23

3-6. Cross Section of Carlsglück Shaft Plug (From Klemme, 1979) . . . . . . . . . . . . 28

3-7. Schematic of Service Shaft at Cote Blanche Mine . . . . . . . . . . . . . . 31

\section{Tables}

2-1. Companies Contacted for Concrete Usage in Mines . . . . . . . . . . . . . . . . 10 


\section{NOMENCLATURE}

$\begin{array}{ll}\text { CSR } & \text { Chemical Seal Ring } \\ \text { DOE } & \text { Department of Energy } \\ \text { DRZ } & \text { disturbed rock zone } \\ \text { EPA } & \text { Environmental Protection Agency } \\ \text { MSHA } & \text { Mine Safety and Health Administration } \\ \text { PCA } & \text { Potash Corporation of America } \\ \text { TRU } & \text { transuranic } \\ \text { WIPP } & \text { Waste Isolation Pilot Plant }\end{array}$




\subsection{INTRODUCTION}

A survey was conducted of materials that have been used in underground salt and potash mines for sealing and plugging purposes. Information reviewed included materials, specifications, design details, construction methods, testing methods and results, and performance evaluation. In general, the experience base is small because few shafts and underground drifts in evaporite mines have been sealed or plugged in the United States and Canada. Because of the lack of information, the survey was expanded to include salt solution-mining and salt cavern-storage industries, which routinely seal the borehole annuli between salt and permanent casings.

\subsection{Task Description}

\subsubsection{Plan}

The purpose of this survey was to review experience using concrete for seals within the salt and potash industries. This work was undertaken to establish a basis for performance expectations of potentially similar structures in the seal system at the Waste Isolation Pilot Plant (WIPP). Although the emphasis was on the use of salt-saturated concrete, information on other materials of potential use in the WIPP seal system (such as reconsolidated salt, bentonite, chemical seal rings, and asphalt) was also obtained. The initial objective was to identify, contact, and visit mines that have installed concrete structures under ground. Engineering personnel at more than 30 mines were contacted (1) to determine if they had installed concrete structures in the mine; (2) to obtain information about the purpose of any concrete structure, its age, construction methods, problems to date, and any other information such as rock mechanics measurements; and (3) to inquire about the possibilities of visiting the mine to obtain additional information. Table 1 lists the companies contacted during this survey. Of these, five mines were visited to obtain first-hand information relating to concrete seals.

\subsubsection{Results}

The survey identified only a few salt or potash mines in North America that have constructed concrete structures under ground for purposes other than shaft linings and foundations for equipment. Those mining companies that have constructed bulkheads for water control purposes were generally willing to discuss their applications. Discussions were limited in one case because of pending legal issues associated with water inflow. Some operators may be willing to allow underground experimental work to obtain concrete samples from applicable structures. 
None of the mines contacted had used materials such as bentonite or reconsolidated salt to form barriers under ground, except for the use of uncompacted salt as ventilation brattices. Some mines use waste salt to backfill mined out areas to limit closure between the floor and back. This salt is not mechanically consolidated after being stowed, and no measurements are made after it has been in place to determine the amount of compaction that has occurred.

Because of the limited number of concrete sealing structures in North American salt and potash mines, the survey was expanded to include literature searches for structures in salt or potash mines in Europe. This search provided some data on bulkheads constructed in German potash mines either for conversion to crude oil storage or during abandonment to provide research data for their radioactive waste program. Additional information is available in German publications that have not been translated into English.

The field of interest for the survey was further expanded to include experiences in constructing, repairing, or sealing shafts into salt and potash mines. Data concerning shafts were obtained almost exclusively from the literature. This review provided numerous case histories of shaft construction or repair, but it provided few technical details, such as concrete mixes or thicknesses, and little data on the long-term performance of the shaft liners or subsequent repairs.

Additional literature reviews and telephone contacts provided information on the experience of the oil and gas industries and the salt solution-mining and cavern-storage industries in sealing wellbores with cement. These industries utilize strings of steel pipe (casing) cemented into a wellbore to provide access to the mineral deposit being exploited. There is a great wealth of information on the process of cementing casing into wellbores, an activity that has been practiced since the early $1900 \mathrm{~s}$. Little information is available, however, on the longevity of the cement or evaluations of the cause of long-term cement/casing failures in wells. There is also very little data that specifically relates to cement in contact with salt. Consequently, the results of these reviews and contacts are not included in this report.

\subsection{Waste Isolation Pilot Plant Seals Program}

The U.S. Department of Energy (DOE) is developing the WIPP facility in southeastern New Mexico to demonstrate the safe disposal of transuranic (TRU) radioactive wastes arising from defense activities. The WIPP waste disposal horizon lies in a bedded salt formation approximately $2,150 \mathrm{ft}(655 \mathrm{~m})$ below ground surface. Four shafts have been constructed for operations of the WIPP site. These include an air intake shaft, an exhaust shaft, a waste handling shaft, and a man-and-materials shaft. Regulations

specify that the shafts not become preferred pathways for fluid migration into or out of the repository. It is the sealing of these shafts for which the analog studies may be most directly useful. 
Preliminary concepts for the WIPP seal system and work to validate these concepts are well documented in a series of reports (e.g., Stormont 1984, 1988; Stormont and Argüello, 1988). The initial reference seal design (i.e., preliminary conceptual design) is given by Nowak et al., 1990. Alternatives to the reference design are described by Van Sambeek et al., 1993. Shaft seal design is ongoing at Sandia National Laboratories. A major milestone for shaft seal design and system modeling is a design to be included in a compliance submittal to the Environmental Protection Agency (EPA).

Shaft seals will be installed at the WIPP to achieve the following objectives:

1. To reduce, to the extent practical, emission of volatile organic compound gases and brine from the repository through the shafts and to the accessible environment.

2. To prevent groundwater above the Salado (salt) Formation (which contains the repository) from saturating the reconsolidating salt seal materials in the shafts.

3. To retard flow within the shaft between water-bearing units above the Salado Formation.

Performance objectives have different durations or time periods for their application. Objective 1 is applicable for the entire regulated life of the repository, 10,000 years. It is an underlying design requirement that the shafts do not become preferred pathways for fluid transport. The second objective must be achieved to protect reconsolidating salt in lower sections of the shaft seal system. A model for reconsolidating salt and its permeability-density function are being actively developed. The time required for crushed salt to reconsolidate to an acceptable performance level is estimated to be of the order of 100 years or less. Objective 3 is based on state of New Mexico regulations that include the term "permanent." The length of the performance period requires definition based on other state of New Mexico statutes. Recent design considerations have included redundancy in the permanent seal components by adding viable long-term materials, such as bentonite or asphalt.

During the short-term period of less than 100 years, seal components other than salt are expected to achieve sealing objectives. Candidate materials are concrete, bentonite or other clays, bitumen, and cementitious grouts. These materials must not degrade unacceptably during the designed usage period. Short-term materials may degrade in the long term, however, because long-term seal materials are sufficient for isolating the repository and confining all waste within the Salado Formation. If short-term materials do not degrade appreciably during the long-term period, they add confidence to the performance of the seal system. 


\subsection{Potential Seal Materials}

All materials proposed as shaft seal components at the WIPP possess inherently low permeabilities and long-term chemical stability. Design of the shaft seals includes functional redundancy and use of differing materials.

\subsubsection{Concrete}

Where concrete is to be placed against halite (salt), a salt-saturated concrete is generally used. Saltsaturated concrete provides a strong bond between the set product and the host salt (Smith, 1990; Wakeley et al., 1993). Freshwater concrete would dissolve part of the host salt, preventing bond development and allowing migration of fluids along the concrete/salt interface. Salt-saturated concrete is not a new material, as it has been used since the 1940s when salt was added to the cement used for completion of oil wells in salt domes (Slagle and Smith, 1963). Other benefits of adding salt to concrete are improved resistance to deterioration in high-magnesium brines, such as those found at the SaladoRustler contact at the WIPP (Lambert, 1994); set-accelerating or set-reducing (depending on the concentration) and water-reducing effects; and dispersant effects (Smith, 1990).

When a concrete is intended to be salt saturated, a sufficient amount of salt must be available to saturate the mixing water. The salt can be either added as an aggregate or be predissolved in the mixing water. Clean salt should be used to avoid introduction of nonhalite salts (which might accelerate cement hydration) and other minerals such as clays and anhydrite, which can also affect the workability and strength of the concrete.

\subsubsection{Bentonite and Other Clays}

Considerable research has been performed on the use of bentonite as a sealing material for nuclear waste repositories (e.g., Pusch, 1979). Additionally, considerable research has been performed on the use of clays as sealing material for landfills and other waste storage sites. Bentonite and other smectitic clays will swell in contact with water. Swelling in the presence of brine is less than that experienced with pure water, so clay application in the WIPP seals is under investigation. Under ideal confined conditions, swell pressures up to $50 \mathrm{MPa}$ have been measured. Swell pressures depend on the dry bulk density and salinity of imbibed fluid. Other attributes of clays as sealing material are low permeability, wide availability, and workability for meeting different needs. 


\subsubsection{Bitumen}

Bitumen is a water insoluble hydrocarbon material that is viscoelastic at temperatures encountered at the WIPP. It is stable in the presence of brines, chlorides, sulfates, and nitrates. Bitumen has been extensively used, particularly in Germany, to form a seal at both the bottom of the liner and the interface of the shaft lining and the rock wall. Bitumen is generally mixed with an aggregate such as sand to increase its specific gravity so that the resulting asphalt (1) is capable of overwhelming the hydrostatic pressure of groundwaters and (2) will not float on water. Oellers (1983) provides a description of the use of asphalt. A significant advantage of asphalt and bitumen is their ability to flow into fractures and pores in the rock and seal them. According to Oellers, this flow will continue indefinitely, but the rate of penetration decreases as the depth of penetration increases so that the amount of flow becomes insignificant from the viewpoint of loss of material from the sealing area. Sitz et al. (1989) provide a conceptual discussion of the benefits of using bitumen in the sealing of shafts. The use of pure bitumen to seal off water leaks into two potash mine shafts in the former Soviet Union is described by Thomas (1957). The bitumen discussed by Thomas was used as a grout and not directly as a shaft seal to cut off water inflows that conventional cementitious grouts had been ineffective at stopping. In these two cases, the bitumen was injected through drillholes from both the surface and the shaft.

In addition, to its use as a seal component, bitumen could be used to coat and seal concrete elements above the Salado to protect against chemical degradation.

\subsubsection{Grouts}

Grouting involves pressurized injection of fluid materials into rock fractures or interfaces between rock and structures to block or reduce the aperture as a means of preventing fluid flow. Grouting is common in mines and tunnels as a method of controlling or containing water flows. Despite its wide use, grouting remains almost an art for which writing rules and procedures is generally not feasible because of the varying conditions of the rock, the structures involved, and the types of grout available. There are four basic types of grouting materials: portland cement, asphalt, clay, and chemical grouts. Portland cement and chemical grouts are the most common and are discussed below.

Additionally, grout should have the following favorable characteristics:

- High resistance to chemical reaction/degradation.

- Low permeability.

- Ability to "self-heal" if fractured.

- A compressive strength close to that of the country rock.

- Favorable rheology (viscosity, yield strength, adequate period of injectability, and reasonable set time). 
- Zero "bleed" (water, which separates when the grout hardens).

\subsubsection{CEMENTITIOUS GROUTS}

Portland cement is the most widely used grouting material because of its low cost, availability, and historical usage. Neat cement grout consists of portland cement and water, but admixtures are available to alter its characteristics. There are five types of portland cement and any may be used for grout. Each has been formulated to attain certain desirable properties, such as low heat of hydration, chemical resistance, and high early strength. The choice of cement type depends on the application.

Admixtures are finely ground materials added to neat cement to improve or achieve a specific characteristic. Calcium chloride, sodium chloride, sodium silicate, and gypsum, when used in small amounts ( 2 to 4 weight percent), act as accelerators and decrease the setting time of the grout. Decreasing the setting time may be necessary to reduce grout migration, to prevent erosion of new grout by groundwater, and to increase the rate of strength gain (high early strength). Sodium chloride and calcium lignosulfonate are setting retarders (i.e., used to increase setting time). These admixtures allow the grout to migrate further before setting.

Fly ash and pozzolans (dominantly amorphous silica) are used to improve pumpability and as lightweight fillers (up to 50 percent by weight). Fly ash and pozzolans react chemically with the cement and may improve bonding characteristics. Other admixtures include bentonite, which is used to increase water content and to reduce the unit weight of the mix; latex additives, which improve bonding and increase grout resistance to acids and corrosive solutions; and aluminum powder, which increases viscosity and provides good volumetric stability.

The water-to-cement ratio for portland cement grouts depends on factors such as the size and amount of porosity to be filled (including fracture or interface apertures), the amount of water the strata bear, and experience. The water-to-cement ratio can range from 1:1 to 4:1. Generally, a thin grout is used to start the operation and if the strata accepts the grout without pressure buildup, the grout is gradually made thicker. Successful grouting depends on being able to estimate the volume of grout required within a certain rock volume to be grouted. Injecting too much grout flushes grout through the porosity and begins to fill voids in areas beyond the intended area. This can lead to blockages when the overflow areas are grouted. Underfilling the porosity in the planned volume occurs when the grout has too high a viscosity, the injection pressure is too low, or injection is suspended before refusal occurs.

All cementitious grouts contain particles; i.e., they are not simple fluids. At the WIPP, the objective is to penetrate and seal microfractures (aperture less than 100 microns) in the DRZ. To accomplish this, the maximum particle dimension should be no larger than one-third of the aperture. A cementitious grout developed by Sandia National Laboratories (called ULTRAFINE) is produced in a dry form suitable for 
mixing at the site. Ninety percent of the particles are smaller than 6 microns, averaging 2 microns. The material consists of Type 5, sulfate-resistant portland cement, pumice (pozzolan - dominantly amorphous silica), and a superplasticizer. Portlandite (lime) is the most soluble constituent of the hardened cement paste. The pozzolan reacts with the lime, converting it to a low soluble calcium trisilicate. Additionally, the pozzolan results in smaller $(1$ micron) pores that are not connected, resulting in extremely low permeability. Pozzolan replaces much of the portland cement, greatly decreasing the heat of hydration.

\subsubsection{CHEMICAL GROUTS}

Chemical grouts typically consist of two or more components that are mixed before or during injection. Polyacrylamide injects as a monomer, avoiding degradation as it undergoes laminar flow in fractures and changing to a polymer at a predetermined time. Polyacrylate behaves in a similar manner. These inject as fluids with a viscosity only slightly greater than that of water, and penetration of fractures is excellent. Both, however, suffer syneresis (water loss) when compressed or placed in a desiccating environment. Additionally, acrylamide is a known neurotoxin and a suspected carcinogen, while polyacrylate can cause serious burns. Both are considered environmentally undesirable. Use of chemical grouts is relatively recent (compared to portland cement) and their longevity is unknown. Chemical grouts are not proposed as components of the WIPP shaft sealing system.

\subsubsection{Crushed Salt}

Crushed salt conceptually may be an ideal sealing material within the Salado Formation because it is fully compatible with the intact salt and will eventually attain fluid flow properties approaching those of intact salt. Although reconstituted salt has never been used before as a seal material, it has been proposed as a dominant long-term component for the WIPP shafts since the initial concept of waste isolation in salt geologic media was formulated. Density, permeability, and mechanical response of crushed salt depend on its initial placed density and subsequent reconsolidation. The Salado Formation salt will flow (creep) toward the shaft opening as long as a stress difference exists. Creep closure will densify crushed salt placed within the shaft. It has been demonstrated that crushed salt may be compacted to high density ( $90 \%$ of intact density) and low permeability on a large scale (Ahrens and Hansen, 1995); it is expected to function as an excellent seal.

\subsubsection{Hydrophilic Seal Material}

The only hydrophilic seal material identified as being used in mining is the Chemical Seal Ring (CSR) manufactured by Dowell/Shlumberger. The CSR is composed of elastic polymers that are mixed with catalysts and water to form a pliable solid. The CSR materials can be used as either preshaped solid 
elements in a fashion similar to gaskets or as a pumpable liquid that is allowed to set in place. Chemical seals absorb water, resulting in swelling of the seal material. As the material swells, it exerts pressure against its restraints. The amount of pressure developed depends on the degree of confinement, the amount of air in the seal area, and the amount of water available for absorption. Longevity of the material remains a concern, but chemical seal rings have been used successfully for about 30 years in mining applications and have functioned acceptably at the WIPP.

Thickening and setting times of CSRs are controlled by the addition of a catalyst while mixing the slurry. The CSR sets in an endothermic reaction so that monolithic pours create no heat-related problems. When a CSR comes into contact with water, it imbibes the water and expands. In an unconfined state, the expansion can amount to several hundred percent of the original volume. The addition of inert aggregate to a CSR can reduce by up to two-thirds the length of CSR material required to withstand a given externally applied pressure. Addition of an aggregate also reduces the quantity of CSR material required.

The CSR was initially developed to solve water leakage around a large diameter casing into the Tatum salt dome in preparation for nuclear testing (Fredrickson, 1983). Developed in the early 1960s, it has been used for a large number of nuclear tests as well as seals in mines and miscellaneous borehole casings. Use of CSR material in mines includes creating seals in both shafts and bulkheads. Typically in shafts, the CSR is applied as an annular band up to about $2 \mathrm{~m}$ in height to fill the void between the shaft liner and the wall rock. Cleasby et al. (1975) and Tivas (1983) describe case histories of the CSR used as shaft seals for potash mines.

\subsection{Organization of the Report}

This document includes five chapters. Chapter 2.0 describes the process used to elicit information about U.S. and Canadian salt and potash mines, the salt storage-cavern industry, and the nuclear waste program in Germany. Chapter 3.0 provides engineering details of potential WIPP analogs. Chapter 4.0 contains concluding remarks, and Chapter 5.0 is a reference list. Appendix A is a description of a field trip to inspect concrete bulkheads in two Canadian potash mines. 


\subsection{RESEARCH DESCRIPTION}

Prior experience in the use of potential seal materials in salt and potash mines was the basic requirement of this analog study. In that regard, an attempt was made to contact a representative of every salt and potash mine in the United States and Canada. Initially, the research focused on the use of concrete in these mines, but questions were also asked about other materials and methods used to waterproof shafts. Later, because the analogs database was still sparse, the research was expanded to include the solution-mining and oil industries' cementing experience in salt formations. Finally, the investigation was extended to the European salt mining industries and nuclear waste programs, particularly the German program. Table 2-1 contains information on the contacts made in relation to this study.

In North America, several salt and potash mines have constructed substantial concrete structures in mine workings to control water inflows into or through the mine. Only four sites were actually visited under the auspices of this study. Two potash mines in Saskatchewan, described in Section 3.1, were contacted for information, and site visits were arranged to inspect the facilities underground (see Appendix A). The only major use of concrete seals in the United States is at the DOE's Weeks Island Strategic Petroleum Reserve (SPR) site, which is also described in Section 3.1. The Eddy County Mine in New Mexico, which uses concrete for structural elements, was also visited. No applicable analogs exist at the Eddy county mine; however, old concrete cores were recovered for possible degradation evaluations.

To supplement the results of the North American mining inquiries, a literature search was performed for other applications of concrete structures in salt mines. This search yielded data on some bulkheads constructed in Germany that are described in Section 3.1.

Literature after 1978 was reviewed for information on construction and repairs of shafts into salt mines. This review provided data on several shafts in the United States, Canada, Great Britain, and Germany that are described in Section 3.2. Much of this information relates to groundwater control in shafts above the salt zone. Additional information is available in German language publications, but no attempt was made to have these articles translated. The articles cover both experiences with mine shafts and studies of bulkheads conducted for the German nuclear waste program. 
Table 2-1. Companies Contacted for Concrete Usage in Mines

\begin{tabular}{|c|c|c|c|c|}
\hline Company Contacted & Mine Location & $\begin{array}{l}\text { Mine } \\
\text { Type }\end{array}$ & $\begin{array}{l}\text { Concrete } \\
\text { Structures } \\
\text { Used }\end{array}$ & Type of Structure \\
\hline $\begin{array}{l}\text { AKZO Nobel Salt Inc. } \\
\text { AKZO Nobel Salt Inc. } \\
\text { AKZO Nobel Salt Inc. } \\
\text { Carey Salt Co. } \\
\text { Cargill Salt Co. } \\
\text { DynMcDermott/DOE } \\
\text { Hutchinson Salt Co. } \\
\text { Independent Salt Co. } \\
\text { Lyons Salt Co. } \\
\text { Morton Int. Salt Div. } \\
\text { Morton Int. Salt Div. } \\
\text { Morton Int. Salt Div. } \\
\text { Redmond Clay \& Salt Co. } \\
\text { Canadian Salt Co. } \\
\text { Canadian Salt Co. Ltd. } \\
\text { Dow Chemical Canada } \\
\text { Les Mines Seleine, Inc. } \\
\text { Sifto Canada, Inc. }\end{array}$ & $\begin{array}{l}\text { Avery Island, LA } \\
\text { Retsof, NY } \\
\text { Cleveland, OH } \\
\text { New Iberia, LA } \\
\text { Lansing, NY } \\
\text { Weeks Island, LA } \\
\text { Hutchinson, KS } \\
\text { Kanopolis, KS } \\
\text { Lyons, KS } \\
\text { Fairport, OH } \\
\text { Weeks Island, LA } \\
\text { Grand Saline, TX } \\
\text { Redmond, UT } \\
\text { Windsor, Ontario } \\
\text { Pugwash, Nova Scotia } \\
\text { Sarina, Ontario } \\
\text { Magdelan Island, Quebec } \\
\text { Goderich, Ontario }\end{array}$ & $\begin{array}{l}\text { Salt } \\
\text { Salt } \\
\text { Salt } \\
\text { Salt } \\
\text { Salt } \\
\text { Salt } \\
\text { Salt } \\
\text { Salt } \\
\text { Salt } \\
\text { Salt } \\
\text { Salt } \\
\text { Salt } \\
\text { Salt } \\
\text { Salt } \\
\text { Salt } \\
\text { Salt } \\
\text { Salt } \\
\text { Salt }\end{array}$ & $\begin{array}{l}\text { Yes } \\
\text { No } \\
\text { Yes } \\
\text { Yes } \\
\text { No } \\
\text { Yes } \\
\text { Yes } \\
\text { Yes } \\
\text { Yes } \\
\text { Yes } \\
\text { Yes } \\
\text { Yes } \\
\text { No } \\
\text { Yes } \\
\text { Yes } \\
\text { No } \\
\text { Yes } \\
\text { Yes }\end{array}$ & $\begin{array}{l}\text { Shaft Liner \& Floor Pads } \\
\text { N/A } \\
\text { Shaft Liner \& Floor Pads } \\
\text { Shaft Liner \& Floor Pads } \\
\text { N/A } \\
\text { Bulkheads } \\
\text { Shaft Liner \& Floor Pads } \\
\text { Shaft Liner \& Floor Pads } \\
\text { Shaft Liner \& Floor Pads } \\
\text { Shaft Liner \& Floor Pads } \\
\text { Shaft Liner \& Floor Pads } \\
\text { Shaft Liner \& Floor Pads } \\
\text { N/A } \\
\text { Shaft Liner \& Floor Pads } \\
\text { Shaft Liner \& Floor Pads } \\
\text { N/A } \\
\text { Shaft Liner \& Floor Pads } \\
\text { Shaft Liner \& Floor Pads }\end{array}$ \\
\hline $\begin{array}{l}\text { Cominco Ltd. } \\
\text { Eddy Potash Inc. } \\
\text { Great Salt Lake Mineral Corp. } \\
\text { IMC } \\
\text { IMC Fertilizer } \\
\text { Mississippi Potash } \\
\text { Noranda Minerals Inc. } \\
\text { PCS - Allen Div. } \\
\text { PCS - Cory Div. } \\
\text { PCS - Lanigan Div. } \\
\text { Potash Corp. of Saskatchewan } \\
\text { Western Ag-Minerals }\end{array}$ & $\begin{array}{l}\text { Vanscoy, Saskatchewan } \\
\text { Carlsbad, NM } \\
\text { Ogden, UT } \\
\text { Esterhazy, Saskatchewan } \\
\text { Carlsbad, NM } \\
\text { Carlsbad, NM } \\
\text { Colonsay, Saskatchewan } \\
\text { Allen, Saskatchewan } \\
\text { Saskatoon, Saskatchewan } \\
\text { Lanigan, Saskatchewan } \\
\text { Rocanville, Saskatchewan } \\
\text { Carlsbad, NM }\end{array}$ & $\begin{array}{l}\text { Potash } \\
\text { Potash } \\
\text { Potash } \\
\text { Potash } \\
\text { Potash } \\
\text { Potash } \\
\text { Potash } \\
\text { Potash } \\
\text { Potash } \\
\text { Potash } \\
\text { Potash } \\
\text { Potash }\end{array}$ & $\begin{array}{l}\text { Yes } \\
\text { Yes } \\
\text { No } \\
\text { Yes } \\
\text { Yes } \\
\text { Yes } \\
\text { Yes } \\
\text { Yes } \\
\text { No } \\
\text { Yes } \\
\text { Yes } \\
\text { Yes }\end{array}$ & $\begin{array}{l}\text { Shaft Liner } \\
\text { Bulkheads (air) \& Floor Pads } \\
\text { N/A } \\
\text { Bulkhead, Dams \& Floor Pads } \\
\text { Shaft Liner \& Floor Pads } \\
\text { Shaft Liner \& Floor Pads } \\
\text { Shaft Liner \& Floor Pads } \\
\text { Shaft Liner \& Floor Pads } \\
\text { N/A } \\
\text { Shaft Liner \& Floor Pads } \\
\text { Bulkhead } \\
\text { Shaft Liner \& Floor Pads }\end{array}$ \\
\hline $\begin{array}{l}\text { FMC } \\
\text { Rhone Poulenc of WY L.P. } \\
\text { TG Soda Ash Inc. } \\
\text { Tenneco Minerals Co. }\end{array}$ & $\begin{array}{l}\text { Green River, WY } \\
\text { Green River, WY } \\
\text { Granger, WY } \\
\text { Green River, WY }\end{array}$ & $\begin{array}{l}\text { Trona } \\
\text { Trona } \\
\text { Trona } \\
\text { Trona } \\
\end{array}$ & $\begin{array}{l}\text { No } \\
\text { Yes } \\
\text { Yes } \\
\text { Yes }\end{array}$ & $\begin{array}{l}\text { N/A } \\
\text { Shaft Liner \& Floor Pads } \\
\text { Floor Pads } \\
\text { Floor Pads }\end{array}$ \\
\hline
\end{tabular}




\subsection{POTASH AND SALT MINE UNDERGROUND SEALING}

\subsection{Bulkheads}

Bulkheads are barriers built across mined entries to control the flow of liquids, air, or backfill material. Bulkheads built to control air and backfill material are generally neither structurally strong nor leakproof and will not be described in this report. There are no manuals or texts and few published papers available that describe the design and construction of underground bulkheads in evaporite mines.

Bulkheads for the control of water in salt mines are rare. Bulkheads have been constructed in two of the Saskatchewan potash mines to prevent flooding by water from overlying formations that enter the mines through the back or faces of the mined areas. A series of bulkheads have also been built to retard brine inflow into crude oil stored in a converted room and pillar mine for the DOE's SPR (Weeks Island Mine) and to convert a potash mine in Germany to hydrocarbon storage (Hope Mine).

Bulkheads used for liquid control in the few salt mines identified are massive concrete structures that are keyed into the salt deposit. The primary controls for fluid movement are: (1) the blocking of the opening with concrete, (2) flow path length along the bulkhead/salt interface, (3) tightness of the interface, and (4) mitigation of the disturbed rock zone (DRZ). To ensure a tight interface, the concrete is usually salt saturated to minimize dissolution of the salt face by water in the concrete. An alternative means for protecting the salt from water attack is to spray the salt surface with a water-impermeable coating such as epoxy. A secondary seal in the form of asphalt or chemical seal rings is often employed to assure no water movement along the bulkhead/salt interface. In some situations, the interface is also grouted to tighten the contact between the concrete and the salt or to seal the DRZ around the excavation.

The bulkheads are built massively, both to provide strength for withstanding the hydrostatic pressure of the water and loads resulting from salt creep, and to provide a long flow path along the interface to restrict fluid movement toward the free surface. A general rule for bulkhead design is to make the bulkhead twice as long as the largest diagonal in the cross section of the drift. Reinforcing steel is generally not used in mine bulkheads because the loading conditions are mostly compressive and because of potential corrosion problems.

Bulkheads are often built with one or more pipes penetrating them. These pipes provide access for monitoring fluid levels (or pressures) behind the bulkheads or for adding (or removing) fluid from behind the bulkhead. The pipes are positioned in the form prior to casting the bulkhead concrete. Sealing of the pipe penetrations usually relies on adhesion between the concrete and the pipe. Occasionally, a secondary seal such as an asphalt coating on a face of the concrete provides a seal around the pipe. Pipe penetrations are often the source of leakage through bulkheads. 
Sitz (1982) provides general discussion of the design of bulkheads in salt with emphasis on the role of keyways. He recommends the use of truncated cone-shaped bulkheads. He also recommends the use of active sealing systems such as clay and bitumen in front of the structural element of the bulkhead. An active sealing system is one that will move and deform with movements of the host rock to seal any new openings adjacent to the plugged area. Sitz also discusses briefly the use of barricades and rock filling in front of bulkheads to limit diffusion and convection of inflowing fluid. This control of fluid movement allows the water to become saturated, thus limiting dissolution around the bulkhead. Sitz briefly describes bulkheads used to seal shafts in three potash mines but provides little detail and no evaluation of the long-term success of the bulkheads.

\subsubsection{Weeks Island}

The DOE's SPR stores about 73 million barrels of crude oil at the Weeks Island, Louisiana, storage facility. The Weeks Island site is a former room and pillar salt mine acquired from Morton Salt. This mine was developed on two levels. As a part of the conversion from mine to storage facility, Morton developed a small third level (the service level) above the mining levels and an adjacent small temporary mine. This temporary mine (the Markel Mine) is removed from the original mine and was active for about 2 years. A schematic cross section of the site is shown in Figure 3-1. The mine and its conversion to storage are described by PB-KBB Inc. (1982).

The uppermost level (service level) is connected to the storage chamber by two shafts, two raisebores, and the Markel Incline. The Markel Incline was developed by Morton to move their equipment from the old mine to the Markel Mine. The DOE had concrete bulkheads constructed in each of these five passages. These concrete bulkheads have been in place since about 1979 and have provided the primary crude oil containment in entries mined into the Weeks Island storage facility. The original intent of these bulkheads was to isolate the oil from the atmosphere to prevent development of an explosive mixture and to protect the storage chamber from the ongoing Morton mining operations. Additionally, the service shaft bulkhead served as a platform for the submersible pumping system. As designed, the bulkheads were separated from the crude oil by an inert gas pad. With the upgrade to the bulkheads (and later pressurization of the mine) described later in the text, crude oil is now in contact with four of the bulkheads. A gas pad now exists only behind the Markel Incline Bulkhead.

A sixth bulkhead, dating from the time the mine was converted to storage, is located in the Wet Drift on the service level. This bulkhead was constructed to seal potential water inflow from a wet zone in the salt body. This bulkhead is considerably different in construction from the oil isolation bulkheads and will be described separately.

In the early and mid-1980s, the DOE and Sandia National Laboratories reevaluated the geotechnical risks associated with the Weeks Island facility. The major concern identified by this risk assessment 


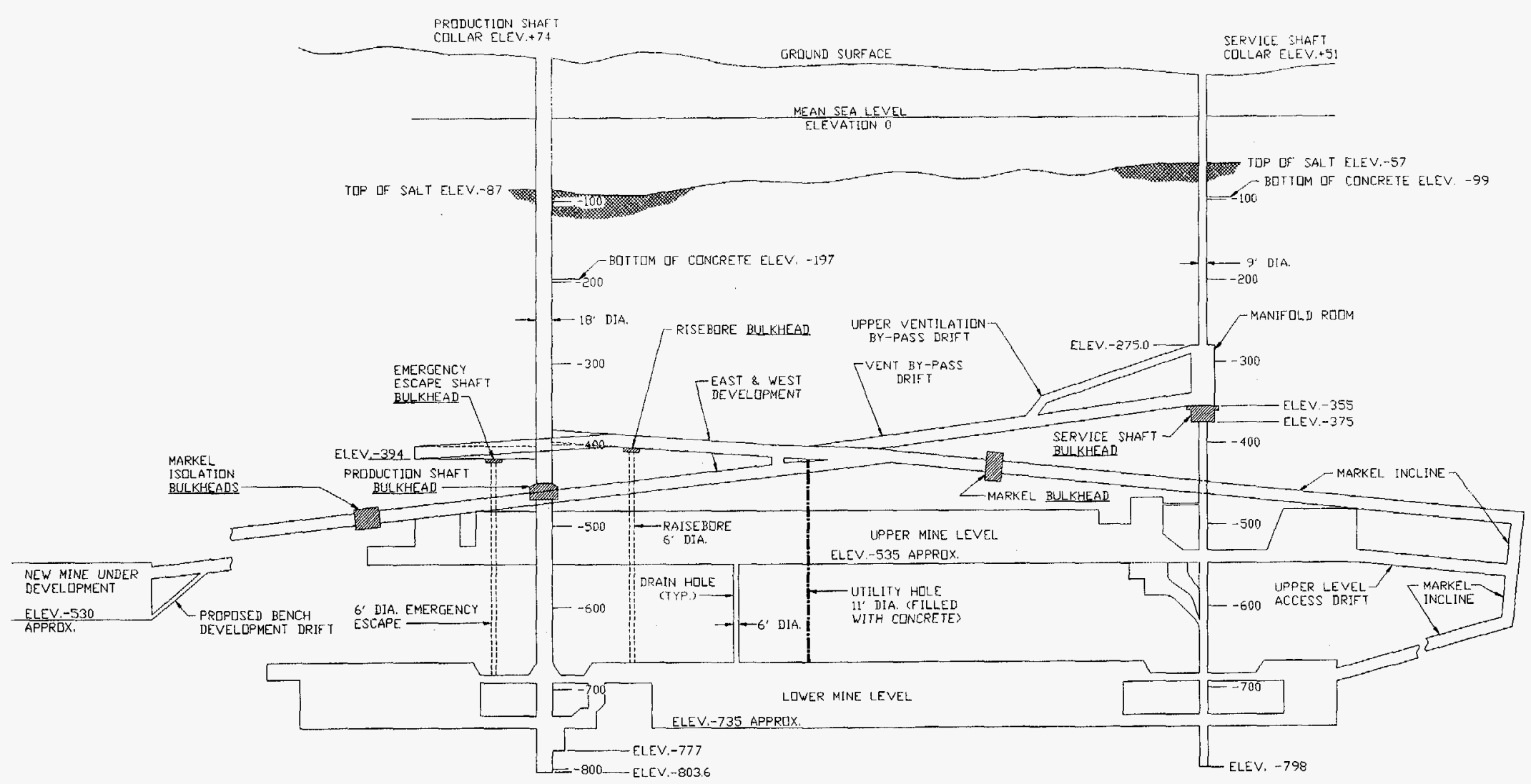

Figure 3-1. Schematic Cross Section of Weeks Island SPR Oil Storage Facility (From Jacobs Engineering Group, 1988b). 
was the danger of water entering the facility through the service level, either at one of the shafts or by a renewed uncontrollable leak in the Wet Drift. A recognized but minor concern was the possibility of water leaking directly into the storage chamber. This reevaluation gave rise to the Risk Abatement Program and an analysis of the capabilities of existing bulkheads to withstand pressure loading from either above or below. The Risk Abatement Program subsequently provided funding for upgrading the existing bulkheads, building two isolation bulkheads in drifts leading to the abandoned Markel Mine, and installing an air drying system to eliminate condensation from ambient humidity in the shafts. Elimination of humidity was necessary to differentiate groundwater leaks from dripping caused by condensation, which was a significant volume in the summer months at the site.

The two additional bulkheads were constructed about 12 years after storage began. These two bulkheads were built to isolate the abandoned Markel Mine from the DOE service level. The primary purpose of these bulkheads was to limit the amount of water that can flow across the oil isolation bulkheads (described above) in the event that one of the shafts fails and allows water to enter the facility. Without the Markel Mine isolation bulkheads, about 5.5 million barrels of water could flow through the service level before the service level and the Markel Mine become inundated. This is sufficient water to potentially leach the salt from around one or more of the oil isolation bulkheads. The Markel Mine isolation bulkheads limit the potential inflow to about 0.5 million barrels of water and effectively preclude the dissolution of enough salt to allow water to bypass an oil isolation bulkhead.

\subsubsection{MARKEL MINE ISOLATION}

Two new bulkheads were built in the Sandrik and Johnston access drifts from the service level to the abandoned Markel Mine to isolate it from the DOE facility (see Figure 3-2). These bulkheads (Jacobs Engineering Group, 1988a) consist of massive concrete with steel tubes and doors to provide access to the Markel Mine. (In the event that a water leak developed in the Markel Mine, the DOE desired to maintain access for possible grouting of the leak.)

The bulkheads were built in two parallel drifts that had been developed by conventional drill-and-blast methods about 14 years before bulkhead construction began. The sides, back, and floor of the drifts were

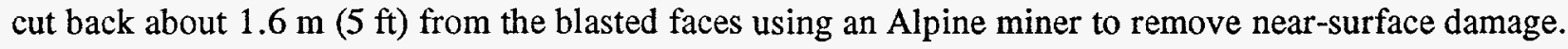
The bulkheads are about $14 \mathrm{~m}(45 \mathrm{ft})$ long, $7 \mathrm{~m}(22 \mathrm{ft})$ high, and $10 \mathrm{~m}(32 \mathrm{ft})$ wide. The bulkheads are constructed in drifts with a downward slope of about 5 percent from the DOE service level. The sides, top, and bottom of the bulkheads are parallel to the axis of the drift and the ends are vertical.

The bulkheads were constructed using salt-saturated mass concrete. The concrete was mixed in a surface batch plant, pumped down the shaft, remixed, and then pumped into the bulkhead forms. No special cooling of the concrete was attempted. A vertical construction joint was left between each pour, although the exposed concrete surface was roughened to improve adhesion between the set and the 


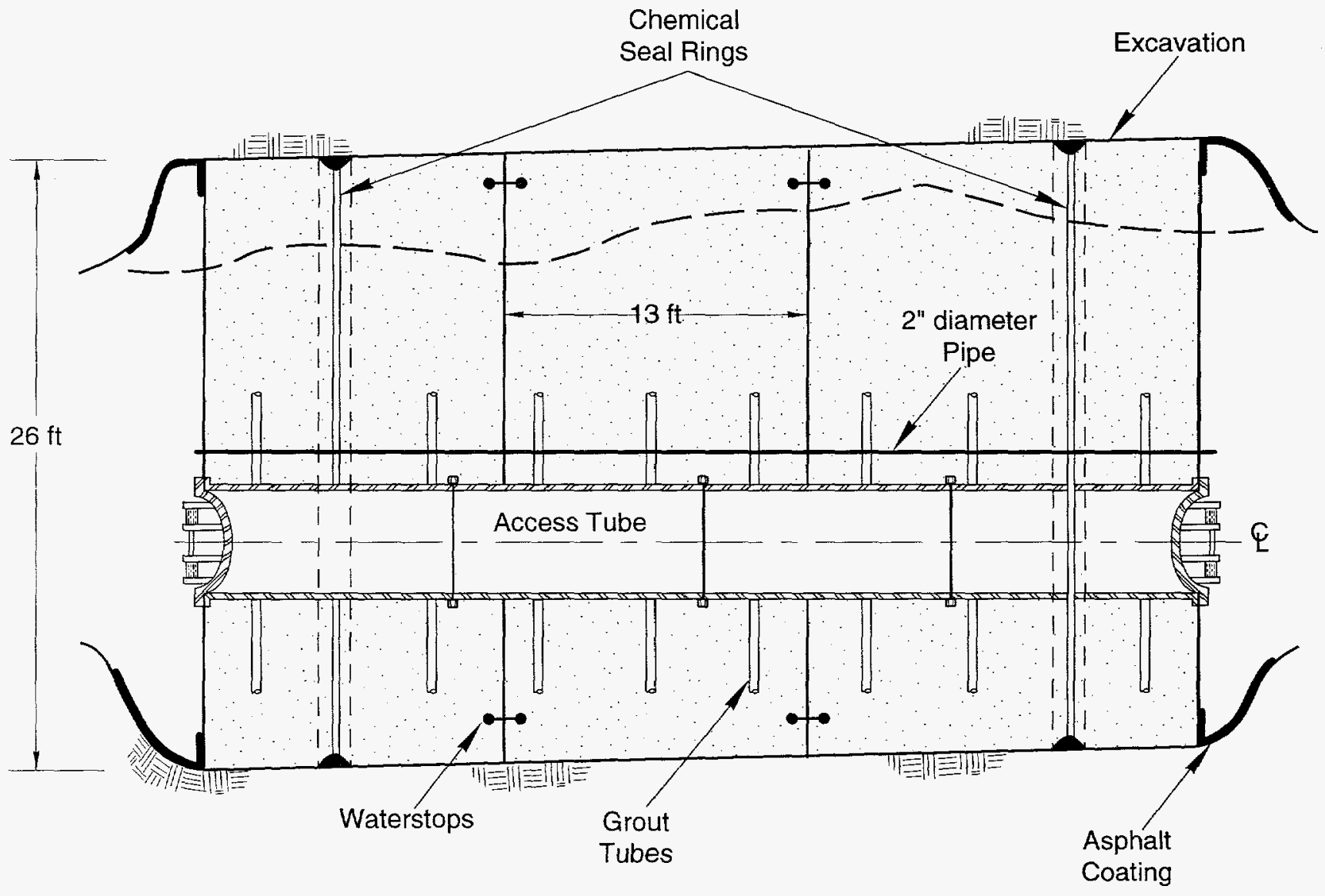

TRI-6121-313-0

Figure 3-2. Weeks Island Sandrik drift bulkhead cross-section. 
new concrete. Because the construction joints are perpendicular to the direction of potential fluid transport, they are not considered important structural features.

The bulkheads utilize two CSRs, used as O-rings, near each face of the bulkheads to seal against water intrusion along the salt/concrete interface. Additionally, the interface was grouted with a polyacrylate grout after construction. Grout tubes were also included in the construction to allow for additional grouting of the bulkhead/salt interface should it become necessary in the future.

Even though performance of the bulkheads has not been measured experimentally, to the observer the concrete appears to be uncracked, minimally segregated, and containing relatively low percentage of entrained air. This salt-saturated concrete was placed in the forms at temperatures exceeding $32^{\circ} \mathrm{C}$ $\left(90^{\circ} \mathrm{F}\right)$ in some cases. Although practice would dictate lower placement temperatures for several reasons, the Weeks Island concrete appears to be satisfactory. Construction of the Weeks Island bulkheads in the Johnston and Sandrik drifts provides confidence that mass concrete, as it would be used for the seal components at the WIPP, can be placed in a hot setting, in large volumes, and with good qualitative mass properties.

\subsubsection{OIL ISOLATION BULKHEADS}

The oil isolation bulkheads are conceptually similar to each other, consisting of a massive concrete layer, a CSR layer, and then another massive concrete layer (Figure 3-3). The bulkheads vary in diameter, length, and (in the case of the Markel Incline) shape. The Markel Incline bulkhead is a rectangular block, and the other four bulkheads are cylindrical. Four bulkheads are located in vertical openings (the shafts and raisebores); the Markel Incline bulkhead is located in a 12 percent incline driven from the lower levels.

The bulkheads each have one or more pipes penetrating them to allow monitoring of the storage chamber. A structural steel framework was used as a form and temporary support for the concrete and was left on the storage side of each bulkhead. The Service Shaft bulkhead also has steel pipe penetrations with a supporting framework for 11 submersible booster pumps for oil withdrawal, a line for a submersible brine pump to remove brine from the shaft sump, and an oil-fill line.

The CSR layer was designed to be about $12.7 \mathrm{~cm}(5 \mathrm{in})$ thick, composed of $10.2 \mathrm{~cm}$ (4 in) of CSR material with a $2.5-\mathrm{cm}$ (1-in) layer of silica flour on top. A 10-mil layer of epoxy concrete adhesive was applied to each lower concrete bulkhead face prior to pouring the CSR. The silica flour was covered with a 4-mil polyethylene sheet to protect it from moisture during the upper concrete pour. The CSR layer also is in place around the lower concrete element of each bulkhead in a slot left around the periphery of the bulkheads and at each pipe penetration. The CSR layer was intended to be both a seal against possible water intrusion from a flooded service level and, primarily, gas migration from the storage 


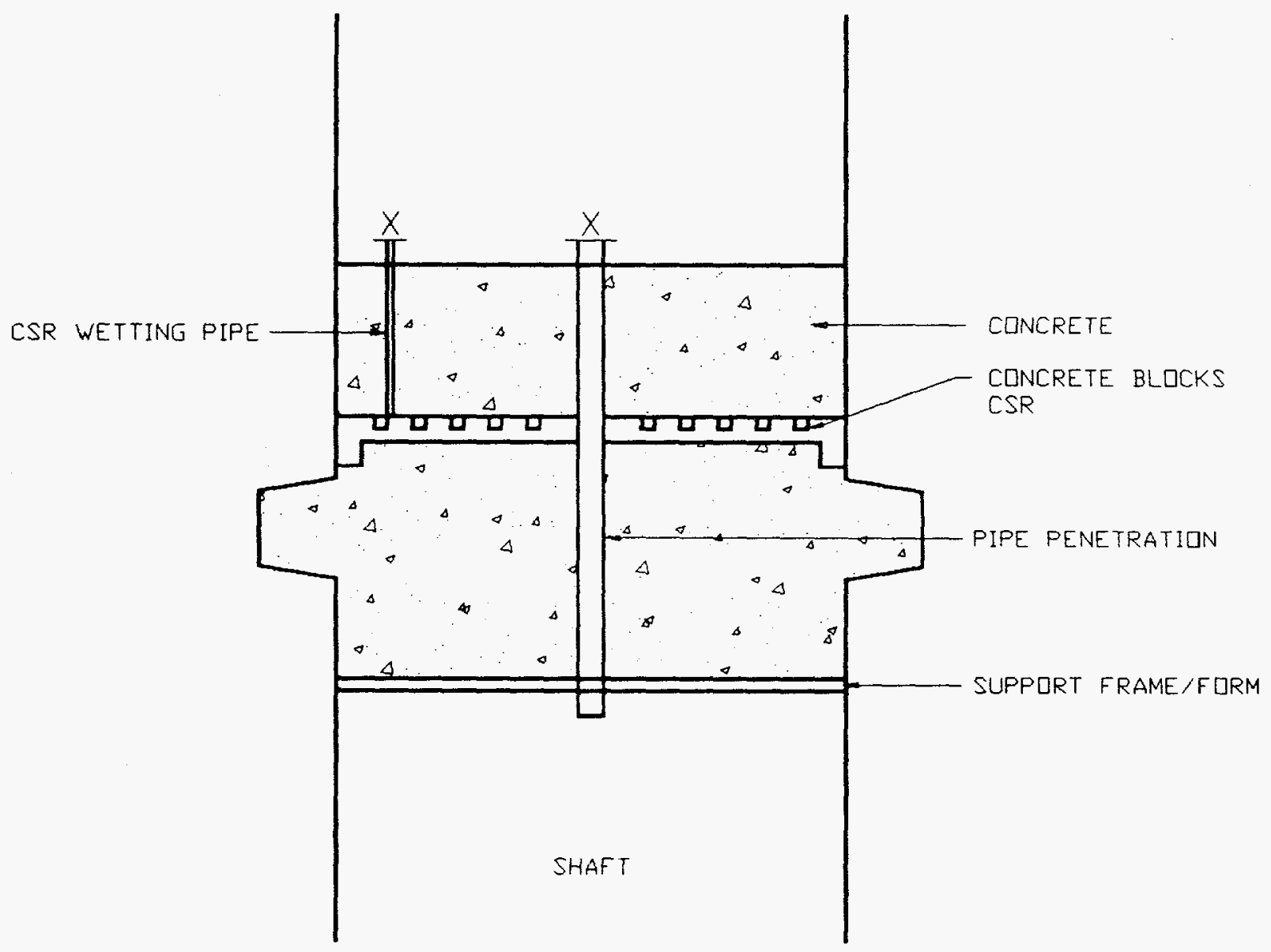

Figure 3-3. Conceptual Schematic of SPR Oil Isolation Bulkheads. 
chamber into the service level. To keep the CSR material activated, a wetting pipe assembly was incorporated into each bulkhead to allow water addition to the CSR material. No means were provided to determine to what degree the CSR was activated.

The bulkheads were designed to withstand an explosion in the storage chamber during filling of the mine and to withstand a full hydrostatic head from the surface on the topside. Consequently, all the bulkheads were keyed into the salt to withstand pressure in a downward direction, but the raisebore bulkheads were not keyed in on their top surface (Figure 3-3). The keyways and slots for the shaft bulkheads were cut by a mechanical miner to avoid blasting damage to the rock surrounding the shafts. The Markel Incline slot and keyway were excavated by hand. The keyways for the raisebores were created by drilling and blasting followed by hand-trimming of the walls.

The design mix for the concrete was a fresh water portland cement-aggregate mix with $20.7 \mathrm{MPa}$ (3,000 psi) 28-day strength and a maximum 10.2-cm (4-in) slump. Subsequent testing of some test cylinders indicated that they did not obtain the designed 28-day strengths, with failures occurring at stresses as low as 15.2 MPa (2,200 psi) (Jacobs Engineering Group, 1988b). All the concrete was mixed in a batch plant on the surface and pumped underground. The concrete was placed into the bulkheads at a maximum rate of fill of $0.6 \mathrm{~m}(2 \mathrm{ft})$ per hour. Ice was mixed with the concrete during construction of the Service Shaft bulkhead to limit the temperature of the pour to $15^{\circ} \mathrm{C}\left(60^{\circ} \mathrm{F}\right)$.

The Service Shaft bulkhead is about $12.6 \mathrm{~m} \mathrm{(40} \mathrm{ft)} \mathrm{in} \mathrm{diameter} \mathrm{except} \mathrm{that} \mathrm{the} \mathrm{upper} 1.8 \mathrm{~m}(5.5 \mathrm{ft})$ were excavated to a diameter of about $14.4 \mathrm{~m}(46 \mathrm{ft})$. The shaft itself is a rectangular opening about 3.1 $\mathrm{m}(10 \mathrm{ft})$ by $3.8 \mathrm{~m}(12 \mathrm{ft})$ below the bulkhead. The bulkhead consists of three concrete layers. The first layer is about $3.5 \mathrm{~m}(11 \mathrm{ft})$ thick with the CSR layer on top; the second layer is about $2.5 \mathrm{~m}(8 \mathrm{ft})$ thick; and the third layer, which was placed directly on top of the second layer, is about $0.9 \mathrm{~m}(3 \mathrm{ft})$ thick. A small square sump was left in the center of the topmost layer to provide a housing for the piping manifolds from the submersible pumps located at the bottom of the shaft.

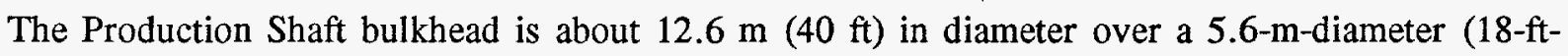
diameter) circular shaft. The bulkhead consists of a 4.2-m-long (13.5-ft-long) lower concrete plug, a CSR layer, and a 6.3-m-long (20-ft-long) upper concrete plug. The upper $0.9 \mathrm{~m}(1 \mathrm{ft})$ of the $\mathrm{bulkhead/salt} \mathrm{interface} \mathrm{was} \mathrm{grouted.}$

The Raisebore 1 and Raisebore 2 bulkheads are almost identical in construction. Each bulkhead is $5 \mathrm{~m}(16 \mathrm{ft})$ in diameter and is located at the top of the $1.9-\mathrm{m}$-diameter (6-ft-diameter) raisebore. The raisebore bulkheads consist of a 1.6-m-long (5-ft-long) lower element, a CSR layer, and a 1.6-m-thick (5-ft-thick) upper concrete element. These bulkheads differ slightly from the other bulkheads at Weeks Island in that they have five rows of resin-set rockbolts inserted through shear clips (channel iron) into the salt to provide anchorage to the walls. 
The Markel Incline bulkhead is a vertical-faced rectangular bulkhead located in a 5.6-m-high (18-fthigh) by 7.8 -m-wide (25-ft-wide) drift that has a 12 percent gradient. A 3.9-m-long (12.5-ft-long) lower concrete bulkhead was placed between steel forms. After the upper steel form was removed, a CSR layer was installed using a steel form, which was stripped after the CSR set. A steel form panel for the silica flour was left in place when the upper 2.5-m-long (8-ft-long) concrete bulkhead segment was placed. The outer steel form was also left in place on this bulkhead after completion, but it was removed at a much later time to allow inspection of the bulkhead surface.

An analysis of the strength of the bulkheads included field observation and coring of the bulkheads as described by Jacobs Engineering Group (1989a, 1989b). Cracks in the upper concrete bulkhead elements were observed by upward percolation of bubbles through brine covering the surface. Jacobs Engineering Group, the architect-engineer, interpreted the cracks to be bending fractures in both of the raisebores and shear fractures at the production shaft. Jacobs Engineering Group postulated that the failures occurred as a result of overpressurization on the concrete structures caused by the activation of the full face CSR layer within the bulkheads.

As part of the field work, all the bulkheads were cored along observed cracks and into the CSR layers. The Service Shaft bulkhead was also cored to intercept the concrete/salt interface. The cores of the concrete were tested and found to have compressive and tensile strengths comparable to medium strength concrete (Jacobs Engineering Group, 1989a). Numerous microfractures were observed in the cores, in addition to macrofractures along which the cores had been taken. Laboratory tests of the concrete from the Raisebore No. 1 bulkhead showed an average tensile strength of about $3.9 \mathrm{MPa}$ (560 psi) and an uniaxial compressive strength (one test) of $54 \mathrm{MPa}(7,800 \mathrm{psi}$ ) (Jacobs Engineering Group, 1989a). The compressive strength was far greater than the 28-day design or measured strengths noted earlier.

The core across the salt/concrete interface in the service shaft contained poor quality concrete at the interface and showed indications of a coating, possibly sodium silicate, which had been applied to the salt face prior to pouring the concrete (Jacobs Engineering Group, 1989b). The coating was intended to prevent the fresh water concrete from dissolving salt before it was fully set. The differential strain analysis of the salt core compared to a differential strain analysis of salt from a nearby drift indicated no development of "clamping stress" in the salt (Jacobs Engineering Group, 1989b). This was also indicated visually as the salt core fell into coarse crystals shortly after being recovered. This condition might be evidence for using salt-saturated concrete rather than ordinary portland cement concrete and a coating in a rock salt environment.

Based on the results of this field work and associated laboratory work, Sandia National Laboratories (Blanford et al., 1990) and Jacobs Engineering Group (1990a) completed final analyses of the bulkhead strengths. The consensus of these analyses was that the two raisebore bulkheads and the Service Shaft bulkhead needed to be reinforced in order to withstand full hydrostatic pressure applied from within the 
storage cavern. This situation could occur if brine leaked into the storage cavern and pressurized it. A concept to reinforce these bulkheads from below, as opposed to adding more concrete on top, was developed and subsequently used. This method utilized several layers of low-density epoxy grouts floated on the oil in the storage chamber (Ehgartner, 1991). After a competent base was developed with the epoxy, the shaft was filled with concrete to near the existing bulkheads and then topped off with additional epoxy to fill the space between the new concrete and the old bulkhead (Jacobs Engineering Group, 1990b). The construction work was completed in 1993.

\subsubsection{WET DRIFT BULKHEAD}

The Wet Drift contains an area where a leak of brine developed while the drift was being advanced. The leak developed slowly and was grouted from the drift. After about 1 year, the leak redeveloped and increased in rate. The increased leak initially could not be controlled but was eventually brought under control by a combination of surface and underground grouting techniques. Grouting from the surface used cement grout, and the underground grouting used both cementitious and chemical grouts. DOE and Morton Salt decided to build a bulkhead (Figure 3-4) with a man and material passage so that the drift could be abandoned if necessary. The bulkhead consists of concrete poured between forms with numerous horizontal cold joints. The bulkhead is keyed into the salt and is about $11 \mathrm{~m}(35 \mathrm{ft})$ long in a $6.3-\mathrm{m}(20-\mathrm{ft})$ by $5-\mathrm{m}(16-\mathrm{ft})$ heading. The key was constructed by drilling and blasting with mechanical scaling of loose material. No CSR material was used in its construction. Construction was completed in 1979 .

The bulkhead was tested with a tracer gas in 1985 (S-Cubed, 1985). This testing showed that the bulkhead concrete was extremely permeable. The permeability was calculated to be equivalent to $4 \times 10^{-12} \mathrm{~m}^{2}$ through a homogenous, isotropic material, or about 200 to 1,000 times larger than the measured salt permeability at the site. The tracer gas was eventually detected behind all the oil isolation bulkheads. The rate of gas leakage from the Wet Drift to Raisebore 2 indicated an effective crack aperture of about $0.0004 \mathrm{~cm}$ over a distance of about $30 \mathrm{~m}$ between the Wet Drift and Raisebore 2 bulkheads (S-Cubed, 1985).

Test drilling of the bulkhead indicated that the concrete is of poor quality overall, with high but unquantified porosity, particularly near the top of the bulkhead. Concrete cores obtained from the bulkhead in 1984 were examined and tested. The concrete was described as a Type V portland cement concrete mixed with water, with compressive strengths ranging from 23 to $36 \mathrm{MPa}(3,300$ to 5,200 psi) and tensile strengths from 2.6 to $3.7 \mathrm{MPa}$ (380 to $540 \mathrm{psi}$ ). The bulkhead faces were coated with an epoxy mortar seal.

Further testing after the epoxy mortar was applied showed that gas continued to leak from the Wet Drift, presumably through fractures in the salt around the periphery of the bulkhead. Rehabilitation 


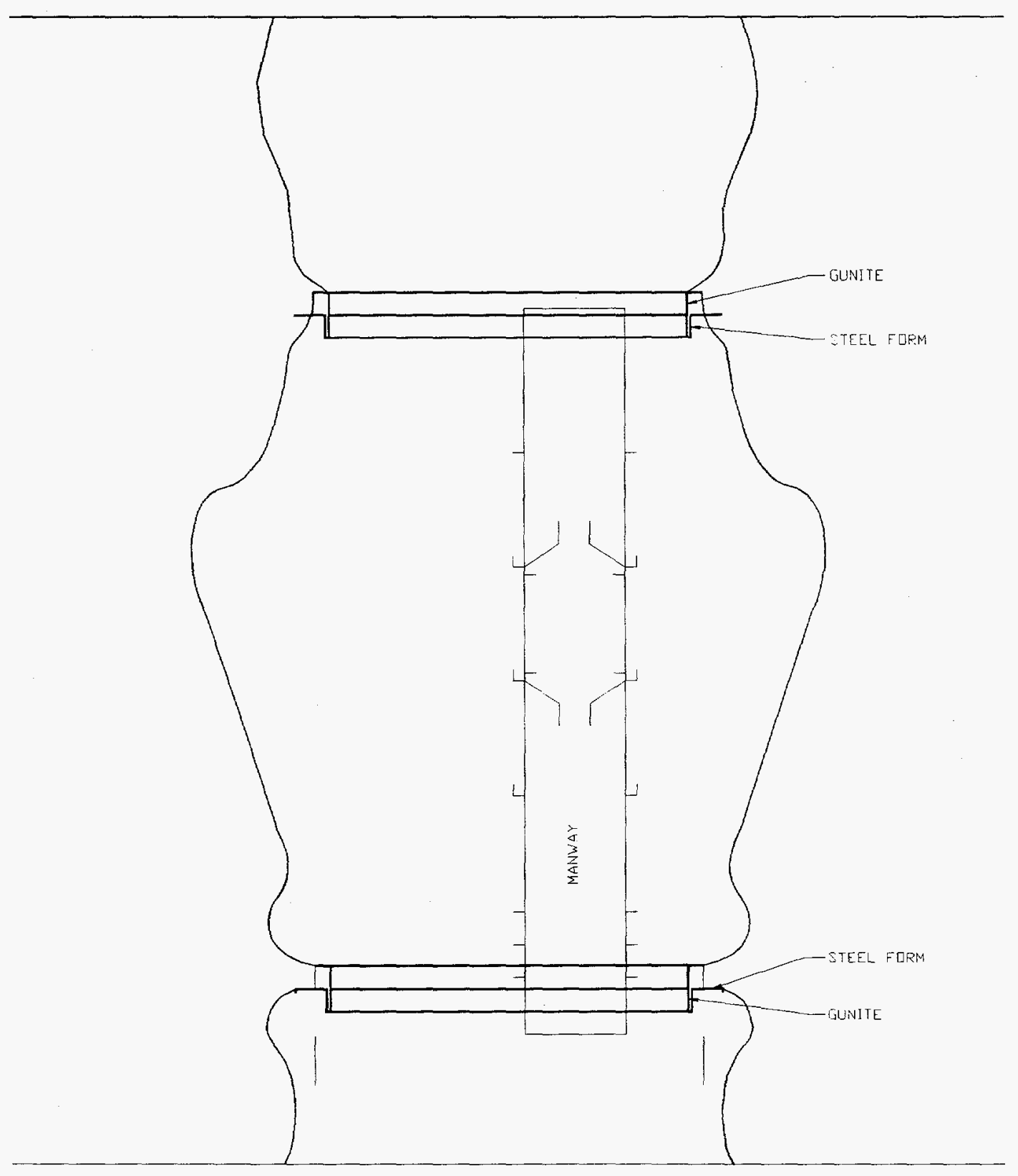

Figure 3-4. Conceptual Plan View of SPR Wet Drift Bulkhead. 
work on the bulkhead continued through 1986 but was unsuccessful in eliminating leakage around the bulkhead. This work consisted of injecting an epoxy grout in approximately 600 holes drilled into the bulkhead. Most grout was injected along concrete cold joints and at interfaces between concrete and pipe penetrations and steel supports. Gas and brine pressure testing of the bulkhead/salt interface and cold joints in the bulkhead itself showed continuing leakage. The bulkhead/salt interface was not grouted, either at the time of construction or during the rehabilitation work.

\subsubsection{Hope Mine}

An abandoned potash mine in northern Germany was intentionally flooded with brine from a solutionmining operation. Prior to flooding, the mine was instrumented to measure the effects of flooding on the mine and salt. As part of the abandonment and test program, a bulkhead was constructed in a deadend drift. The bulkhead was instrumented to determine its mechanical response to loading by the brine as the mine was flooded and to determine if water leaked past the bulkhead. The 500-m-deep (1640-ftdeep) drift was about 20 years old at the time the bulkhead was constructed. This test is described in Herbert and Stöver $(1985,1986)$ and Fischle and Stöver (1986). The following synopsis of the bulkhead experiment is from Fischle and Stöver.

The bulkhead consisted of two salt-saturated concrete elements with a sand-asphalt seal between them, as shown in Figure 3-5. The sand-asphalt mixture was about one-third bitumen by volume with the remainder being 80 percent sand and 20 percent powdered limestone. The concrete mix had a water:cement ratio of $0.5: 1$ with 3 percent salt (by weight). The uniaxial compressive strength of the concrete was $23.7 \mathrm{MPa}(3,450 \mathrm{psi})$. The concrete permeability to brine was about $10^{-18} \mathrm{~m}^{2}$. The outer face of the bulkhead was covered with a membrane composed of alternating layers of bitumen and stainless steel strips. The membrane was supported with a masonry block wall to prevent the strips from peeling away from the face.

The bulkhead had a house-shaped cross section across the drift and a wedge-shaped cross section parallel to the drift. The wedge shape was constructed so that the pressure of the water would force the bulkhead tighter against the salt. A slot was cut into the salt for the sand-asphalt inner seal to prevent migration of brine through fractures in the disturbed salt surrounding the drift. All loose salt around the entry was removed prior to pouring the concrete.

The bulkhead became submerged about 17 months after completion of construction. The data collected showed that the bulkhead locked with the salt about 250 days after construction and developed a frictional connection with the salt after about 500 days. There was no leakage through the bulkhead and no movement of the bulkhead for the first 550 days after it was submerged (the elapsed time to 


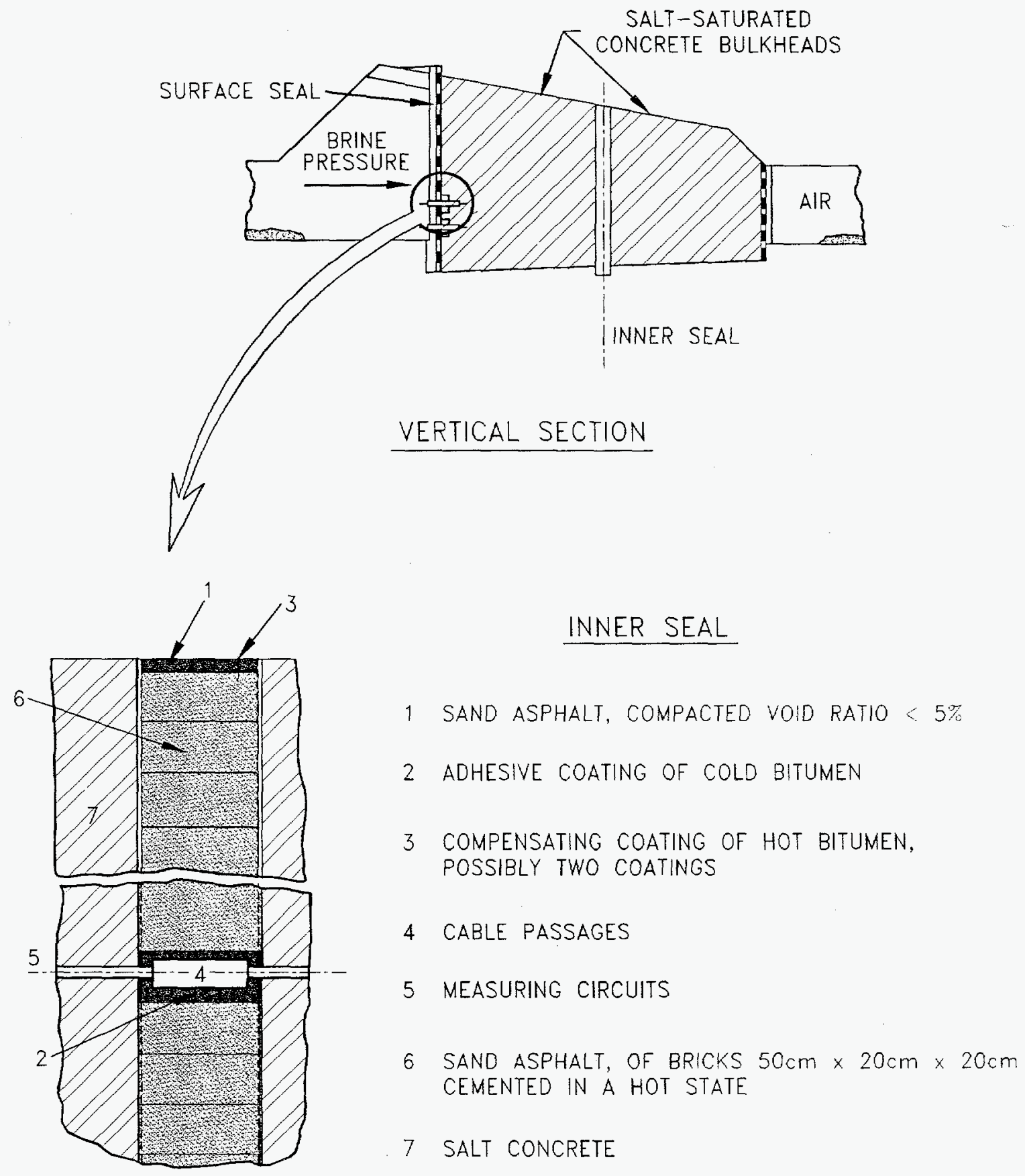

Figure 3-5. Cross Section of Bulkhead in Hope Mine, Germany (From Fischle and Stöver, 1986). 
the date of preparation of the report) (Fischle and Stöver, 1986). This analog site appears to be extremely useful, although follow-up information covering the span of time from 1986 to today has not been collected.

\subsubsection{Rocanville Potash Mine}

In November 1984, brine inflow developed in an isolated room extending from a production area of the Potash Corporation of Saskatchewan's Rocanville Potash Mine. This brine inflow started at about $3 \mathrm{~m}^{3} / \mathrm{min}(800 \mathrm{gpm})$ and increased to over $10 \mathrm{~m}^{3} / \mathrm{min}(2,600 \mathrm{gpm})$ (Prugger and Prugger, 1991). The brine inflow was associated with a collapse structure of the overlying rock units related to paleosolutioning of the salt beds. A concrete bulkhead was erected by late January 1985 to seal off the room, and flow into the mine was completely stopped in March 1985, when valves on relief pipes through the bulkhead were shut. The bulkhead is located in halite, not potash ore. The brine entering the mine was nearly saturated in halite, but substantially undersaturated in potassium and magnesium. If the bulkhead had been in potassium-rich potash ore, dissolution would have been a concern.

Originally, the bulkhead system was designed to consist of a temporary bulkhead and a second, permanent bulkhead. The temporary bulkhead was located about $37.3 \mathrm{~m}(120 \mathrm{ft})$ from the room's face

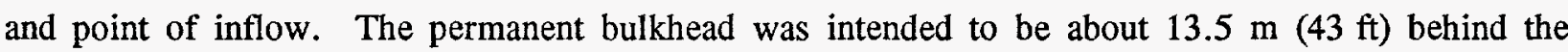
temporary bulkhead. The permanent bulkhead was never built, as the temporary bulkhead proved to be tight, and effectively sealed the brine inflow. The bulkhead has functioned without incident during the 10 years since its completion. Brine pressures of $10 \mathrm{MPa}$ (nearly 1,400 psi) are measured behind the bulkhead.

The construction of the bulkhead is described in a trip report attached as Appendix A. The bulkhead consists of five concrete segments. The innermost (nearest the leak) was a 2.5 -m-long (8-ft-long) structure. A second 2.5-m-long (8-ft-long) dam was built $22 \mathrm{~m} \mathrm{(70} \mathrm{ft)} \mathrm{behind} \mathrm{it.} \mathrm{The} \mathrm{volume} \mathrm{between}$ the two dams was filled with concrete blocks to reduce the amount of concrete needed to reduce the heat liberated during hydration. A third monolithic structure was poured in contact with the second 2.5-m

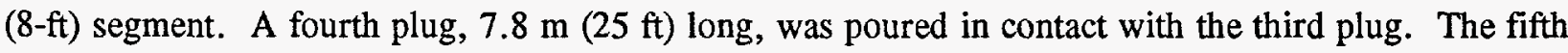
(and last) plug was keyed into the salt in two zones to resist thrust from the inflowing water and was $11.6 \mathrm{~m}(37 \mathrm{ft})$ long.

Chemical seal ring material was used at two locations along the salt/concrete interface. The CSR rings were placed on the outside of the second and fourth concrete segments in an O-ring configuration.

The concrete for the bulkhead segments consisted of cement, fly ash, and crushed granite aggregate mixed with either fresh water or the inflowing brine. The concrete was mixed underground and pumped into forms constructed from wood timbers and plywood and faced with burlap bags. Approximately 100 
pipes for concrete placement, interface grouting, water pumping, and CSR injection were incorporated into the bulkhead, along with one bundle of instrument leads. There is an indication of minor brine leakage around the instrument cable bundle, but nowhere else on the bulkhead, despite the high pressure brine behind the bulkhead.

\subsubsection{Esterhazy (K2) Mine}

In late December 1985, a large inflow of brine developed in the IMC potash mine near Esterhazy, Saskatchewan. The inflow developed in an abandoned section of the mine that was not accessible due to roof collapse and room closure (Prugger and Prugger, 1991). IMC built four bulkheads for water control in 1986 and 1987. Two additional bulkheads were built in 1987 to demonstrate a method to seal the DRZ (Appendix B). The depth of the mine where the bulkheads are located is approximately $990 \mathrm{~m}$ $(3,150 \mathrm{ft})$.

The first four bulkheads (D300, D400, D500, and BF1) were constructed using regular portland cement and aggregate mixed with fresh water and no salt. The concrete mixture consisted of $374 \mathrm{~kg}$ of cement, $1,754 \mathrm{~kg}$ of aggregate, and $170 \mathrm{~kg}$ of water per cubic meter. The concrete was prepared underground in a batch plant which utilized an auger with two reverse blades for mixing. The 28-day strength ranged from 14.8 to $18.3 \mathrm{MPa}(2,140$ to $2,650 \mathrm{psi})$.

The concrete was pumped into wooden forms. The forms were custom cut to the shape of the drift with tolerances of about $2.5 \mathrm{~cm}$ ( 1 in). Burlap was used to fill cracks in the forms and to aid in separating the form from the concrete. The burlap also left a rough, clean finish that would be suitable for bonding to the next pour, if necessary.

The rate of concrete placement was controlled to limit the spreading force on the forms and to avoid the development of a cold joint. The concrete was vibrated in the lower section of the forms, and only pressurized in the upper portions of the bulkheads to eliminate voids. The crown was completed by using a flexible steel mesh. The mesh was placed at the top of the form, and allowed concrete to be pumped against it with pressure. When the pumped concrete pushed against the mesh, concrete oozed out, and the metal mesh flexed to absorb pressure. This reduced the pressure transferred to the wooden form.

The bulkhead in entry D400 is about $2.6 \mathrm{~m}$ (98 in) long and is wedge-shaped to counteract thrust from the water. The bulkhead tapers from $20 \mathrm{~m}(63.8 \mathrm{ft})$ to $17.8 \mathrm{~m}(56.8 \mathrm{ft})$ in width and from $3.5 \mathrm{~m}$ $(11.2 \mathrm{ft})$ to $2.5 \mathrm{~m}(7.9 \mathrm{ft})$ in height. A passageway was subsequently drilled and blasted through this bulkhead. Other than some blasting-induced damage, the only visible sign of deterioration was some minor spalling around the grout pipe penetrations on the outer face of the bulkhead. The interface at the crown appears tight. In an attempt to seal the DRZ, the face of the bulkhead and the drift surfaces $15.7 \mathrm{~m}(50 \mathrm{ft})$ from the outer face of the bulkhead were sprayed with a polyurethane coating. 
The D300 and D500 bulkheads are similar in size and construction. The bulkheads taper from $14.1 \mathrm{~m}$ $(45 \mathrm{ft})$ to $11.2 \mathrm{~m}(35.6) \mathrm{ft}$ in width, and have a minimum height of $2.4 \mathrm{~m}(7.6 \mathrm{ft})$. The bulkhead faces and adjacent drifts were sprayed with polyurethane. The polyurethane is cracked slightly near the roof on the bulkhead surface.

The BF1 bulkhead was built in early 1987 in a drift being mined to intercept a surface borehole to be used to supply backfill material to the mine. The bulkhead was built as a safety precaution in the event the casing of the borehole had not been properly sealed. The bulkhead is at least $6.3 \mathrm{~m}(20 \mathrm{ft})$ wide, 2.5 to $3 \mathrm{~m}$ ( 8 to $10 \mathrm{ft}$ ) long, and $2.5 \mathrm{~m}(8 \mathrm{ft})$ tall. There is a manway constructed in the bulkhead. The bulkhead is at the edge of an abutment area next to a mined panel. Consequently, the stresses are large, and the creep closure of the drift has loaded the concrete structure. A steel liner on the bulkhead has been warped by deformation of the concrete. The concrete on the face of the bulkhead appears to be spalling to a depth of up to $5 \mathrm{~cm}(2 \mathrm{in}$.)

The remaining two bulkheads are part of the B512 bulkhead test, which was designed to determine if the DRZ surrounding excavations in salt can be sealed by utilizing two bulkheads and an overpressurized interval between them. A total of three dams are required to complete the test. The test would consist of placing a fluid less dense than brine, such as diesel fuel, between the outer two bulkheads and brine between the inner two bulkheads. The center bulkhead would be common to the two fluids. The fluids would then be pressurized, with the diesel at a somewhat higher pressure, to determine if brine migration along the DRZ would be stopped by the lighter, pressurized fluid. The configuration of the proposed test is shown in Appendix A, Figure 3.

The first bulkhead for the test was built using a shotcrete technique, and the second bulkhead was

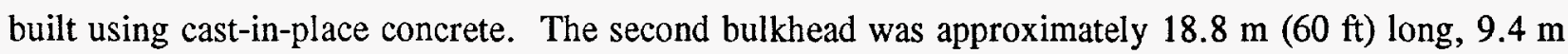

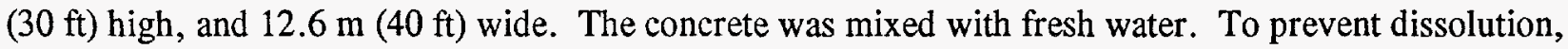
the salt surfaces were coated with a sprayed epoxy prior to pouring the concrete. The bulkhead/salt interface was grouted through tubes placed in the forms. The tubes were porous hoses that were snaked around the interface and brought out the front of the form. The tubes also helped eliminate air pockets. A cement slurry was used to grout the interface.

The full test was not conducted due to failure of the first bulkhead to contain pressure. The bulkhead itself is not pressure tight, apparently because of the shotcrete-style construction method. Also, the DRZ around the first bulkhead was not removed as thoroughly as it was around the second bulkhead. The shotcrete technique and failure to completely remove the DRZ caused the first test bulkhead to leak. The shotcrete failed in part due to a deficiency of air pressure to blow the shotcrete into the room. In order to remediate the shortcomings of the shotcrete, the faces were tarred and cementitious grouting of the salt/bulkhead interface was attempted. However, when the interval between the bulkheads was filled with brine, air leaked profusely through or around the shotcrete bulkhead. 
The cast-in-forms bulkhead appears to be tight in both the concrete appearance and the observable interface. No tests have been conducted to measure the tightness and quality of the bulkhead.

\subsubsection{Wilhelmine-Carlsglück Mine}

As a part of the conversion of the Wilhelmine-Carlsglück Mine, Germany, for crude oil storage, plugs were placed in the two shafts at the base of the tubbing section at about a 170-m (560-ft) depth. The plugs were designed to prevent a washout and to withstand a pressure of approximately $1.7 \mathrm{MPa}$ (250 psi) from above in the event the shaft flooded from the overlying sedimentary sequence. The conversion is described by Klemme (1979), and his description of the bulkheads is summarized below.

The plug in the Carlsglück shaft (Figure 3-6) is approximately $3.5 \mathrm{~m}(11 \mathrm{ft})$ long, and is made from salt-saturated concrete. It was anchored into the salt at an excavation made through the shaft lining. One 812-mm-diameter (32-in-diameter) and four 470-mm-diameter (18-in-diameter) pipes were placed through the seal area prior to placing the concrete. The pipes were coated with Roughcoat (an epoxy sand mixture) to enhance the seal between the steel and the concrete. A bitumen seal and an attempt to grout the interface with a chemical grout were used to achieve a gas- and water-tight seal. The chemical grout (polythixon) was injected through prepositioned grout pipes. While filling the mine with oil, the shaft seal proved not to be gas tight. The leakage is thought to be due to shrinkage of the concrete at the plug/salt interface.

Water accumulates on top of the concrete plug from minor water leaks in the shaft. To prevent the salt/concrete interface from being washed out by the leaking water, a plastic film lining was placed around the top of the shaft bulkhead and anchored to the concrete lining of the shaft. This lining was successful in retaining the water on top of the plug.

The plug in the Wilhelmine Shaft is similar in design and is also not gas tight. The Wilhelmine shaft plug does not have the four 470-mm-diameter (8-in-diameter) pipes penetrating it. An 812-mm-diameter (32-in-diameter) pipe provides access to the mine during final abandonment, when it is no longer used for oil storage.

\subsection{Shaft Liners in Salt}

Conventional salt and potash mines are entered through vertical shafts. These shafts generally penetrate one or more water-bearing zones above the salt layer that need to be sealed off to prevent water entry into the shaft and thus into the mine. Most shafts sunk for this type of mining are lined with either concrete or cast-iron tubbings, although steel/cement composites have been increasingly used as shaft liners in recent times. The liner serves to protect the shaft from closure of the rock, to prevent rock 


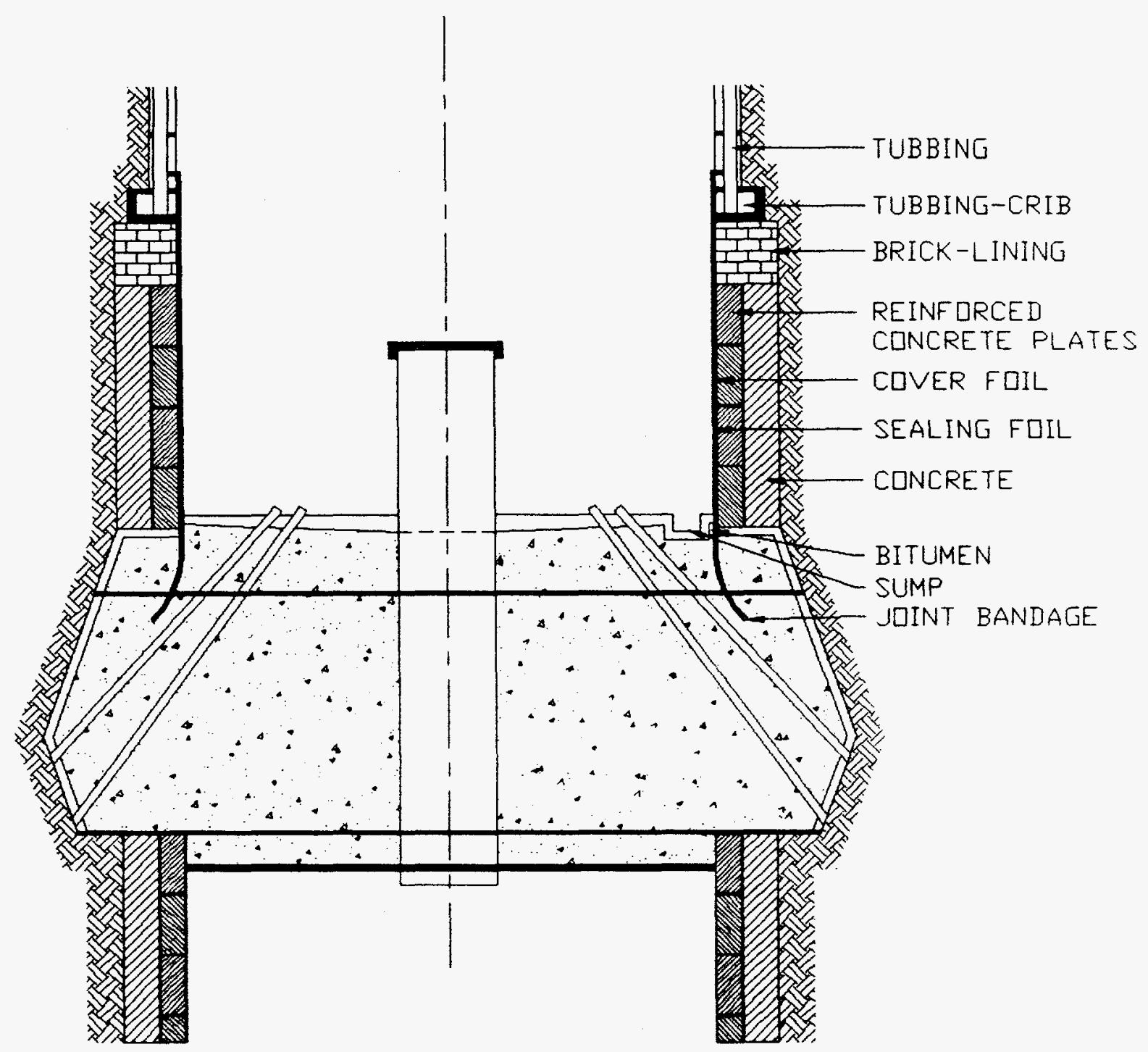

Figure 3-6. Cross Section of Carlsglück Shaft Plug (From Klemme, 1979). 
from sloughing off into the shaft, and to close off water zones penetrated by the shaft. The liners are commonly sealed near the ends to prevent water migration along the rock/liner interface. In recent years, seals in salt mining shafts have been constructed with chemical seal rings or asphalt.

Shafts sunk by European firms (most often German) have typically utilized cast-iron tubbings or steel linings with asphalt seals. North American firms have generally used concrete liners and chemical seal rings. Concrete liners are usually fresh water concrete. A coating is often applied to the salt to prevent salt dissolution. Use of chemical seal rings in the United States and use of bitumen in Europe is not universal, with shaft sinking firms utilizing techniques that have proved reasonably successful in similar ground conditions elsewhere.

Several types of sealing systems are used to prevent water behind the liner from moving along the liner/rock interface and entering shafts. Some of the more commonly used interface seals include pikotage, asphalt/bitumen, CSR and grout. These sealing systems are often used in conjunction with each other. However, in bedded salt mines in the United States, perhaps the most common seal has been adhesion between the concrete lining and the host rock. This is generally an effective seal, in part because most of the host rocks through which the shafts are sunk are relatively dry and impermeable.

Repairs to a leaking shaft involve either grouting or the installation of a new liner. A new liner is generally utilized only after attempts at grouting to stop leaks have proved unsuccessful. Relining of shafts has been relatively common in the Canadian potash mines and the salt and potash mines of Germany. Valk (1989) describes three systems used in Germany by Kali und Salz to restore 14 shafts, most of which were sunk in the early 20th century. The systems described by Valk (1989) are a steel reinforced concrete composite (a reinforced concrete cylinder inside a steel liner) with an asphalt seal, a reinforced concrete liner with a full length asphalt seal, and a steel liner with concrete backfill between the original and new liners, with a CSR seal at the base. According to Valk (1989), shaft liner systems that utilize prefabricated concrete caissons, cast-iron or steel tubbings, and sealing systems such as plastic sheets or clay mixtures are technically and economically inferior to the steel/concrete composite liners. The major problems with the prefabricated systems and plastic sheets relate to ensuring water-tightness at the joints and seams.

Shaft leaks are common, expected, and highly variable. The life of a shaft system depends on the rock type, method and care of construction, intensity of grouting, and degree of maintenance. The remainder of this section will describe general experiences with shaft liners that may be useful analogs to the WIPP seal system evaluation. 


\subsubsection{Cote Blanche}

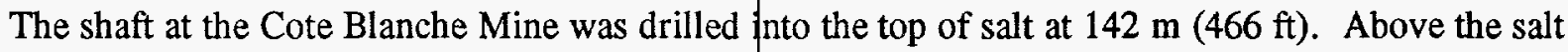
is water-saturated alluvium (clay, silt, sand, and gravel) with an essentially unlimited source of water. The service shaft at the Cote Blanche Mine is unique, because it is the only shaft in the Gulf Coast domal salt mines that was developed by the large hole drilling technique. The shaft was completed in 1963.

The shaft was initially drilled with a 3.28-m-diameter (10.8-ft-diameter) bit to about 171-m (560-ft) depth, and precast concrete caissons (pipes) were used for the liner. The caissons were then cemented into place through tremie pipes in the caisson/borehole annulus. Drilling then resumed with a smaller diameter bit to the final depth of about $412 \mathrm{~m}$ (1,350 ft) with a 2.27 -m-diameter (7.45-ft-diameter) bit. After drilling was completed and the drilling mud renoved from the hole, the caissons were grouted from inside the shaft to eliminate some minor leakage, and a concrete liner and foundation ring was installed from $180 \mathrm{~m}(590 \mathrm{ft})$ to the bottom of the caissons. A pump station was also cut into the shaft wall at $180 \mathrm{~m}(590 \mathrm{ft})$ to $183.3 \mathrm{~m}(601.4 \mathrm{ft})$. A schematic of the shaft is shown in Figure 3-7. The following discussion is after Hart and Fallis (1993).

The shaft remained essentially dry for the first 25 years, with minor leaks that were stopped by remedial grouting. The minor leakage occurred within the $38-\mathrm{m}(125-\mathrm{ft})$ section of the shaft liner that was completed through the salt. The grouting was done using a salt-saturated cement grout followed by a brine-based acrylamide grout. Drilling done for the grouting intersected flows of up to $11 / \mathrm{min}(0.25$ gpm) that continued for extended time periods. These flows appeared to be related to incomplete displacement of the drilling mud while cementing the caissons.

In 1989, a leak was found at about a $185-\mathrm{m}(607-\mathrm{ft})$ depth, below the liner and the pump station. This leak was minor, with a flow of less than $11 / \mathrm{mm}$. Drilling intended to grout this leak found major water flow zones of up to $75 \mathrm{l} / \mathrm{min}(20 \mathrm{gpm}) 15 \mathrm{~m}(49 \mathrm{ft})$ above the pump station and $7 \mathrm{~m}(23 \mathrm{ft})$ into the shaft wall. Additional drilling established the existence of vertical water-bearing zones extending from the top of salt to below the pump station in the shaft within $9 \mathrm{~m}(30 \mathrm{ft})$ of the wall. Based on this drilling, the operator chose to extend the existing liner to ensure that the shaft would not leak unacceptably.

The existing liner was removed below $176 \mathrm{~m}$ blasting to a diameter of about $3.5 \mathrm{~m}(11.4 \mathrm{ft})$ to a depth of about $320 \mathrm{~m}(1050 \mathrm{ft}), 90 \mathrm{~m}(295 \mathrm{ft})$ below the deepest suspected water zone outside the shaft. The new liner was then poured using brine-based (salt-saturated) concrete. The seal between the liner and the salt was enhanced by grouting the interface through eight preset grout pipes. The hole at each grout pipe was drilled $0.5 \mathrm{~m}(1.6 \mathrm{ft})$ into the salt before grouting. Cement grout was followed by acrylamide grout after the holes were redrilled to the original depth. The grouting pressure for both the cement and acrylamide was limited to $3 \mathrm{MPa}$ to avoid damaging the liner. After grouting, the holes were dry packed and capped with a stainless steel plug. 


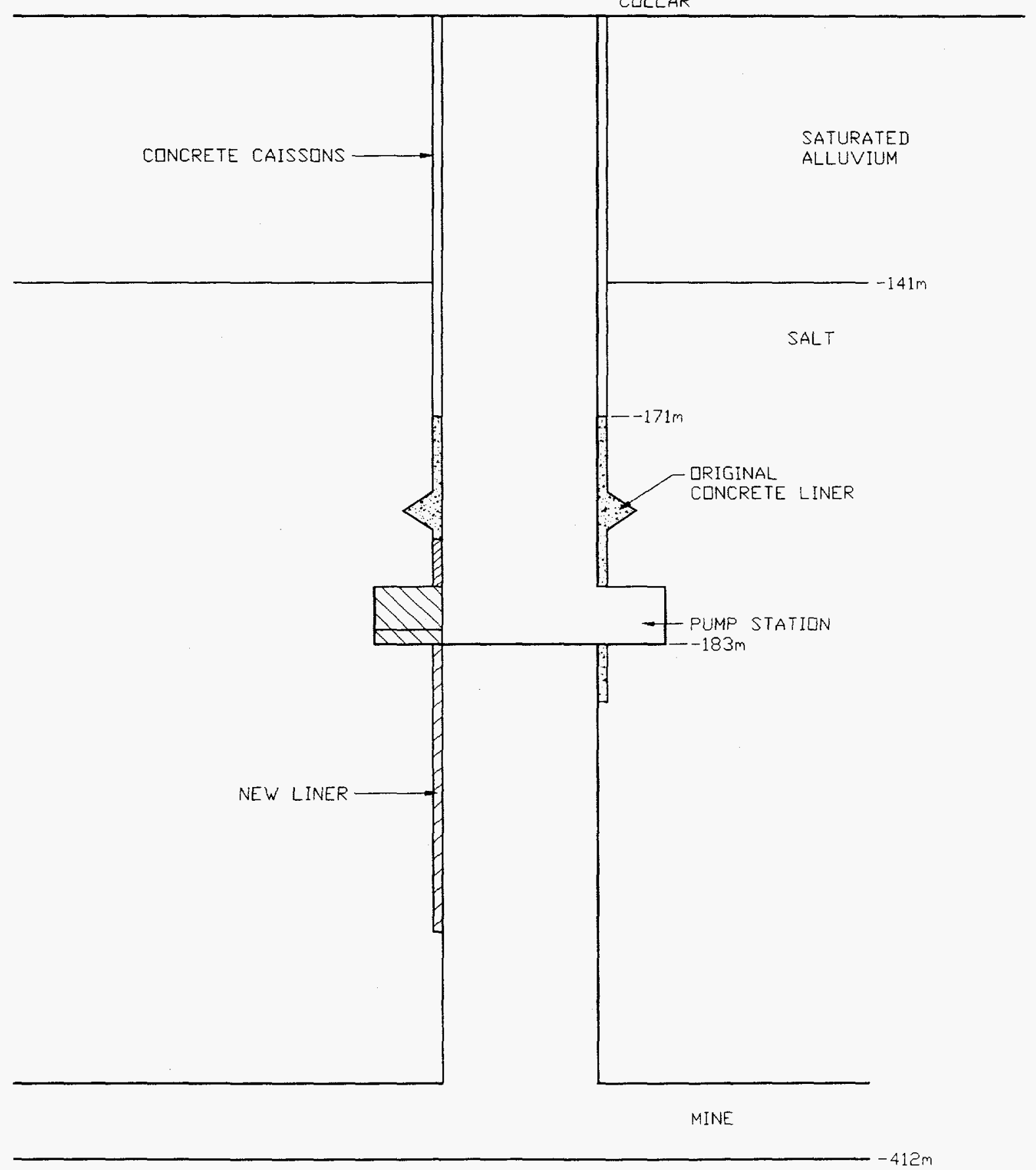

Figure 3-7. Schematic of Service Shaft at Cote Blanche Mine. 


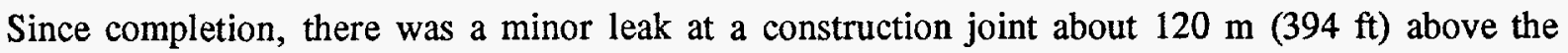
bottom of the liner. This leak was repaired by grouting through the adjacent grout pipes with the twostep program of salt-saturated cement and acrylamide.

\subsubsection{Allen Potash Mine Shaft \#1}

Shaft \#1 at the Allan Potash Mine in Saskatchewan was completed in 1968. In addition to ground freezing, water zones were grouted before and during shaft sinking with cement and chemical grouts. At completion of the shaft, water inflow was less than $0.25 \mathrm{l} / \mathrm{sec}(4 \mathrm{gpm})$. This inflow gradually increased to $1.7 \mathrm{l} / \mathrm{sec}(27 \mathrm{gpm})$ by 1970 . The shaft was regrouted, which reduced the inflow to about $1.5 \mathrm{l} / \mathrm{sec}(24 \mathrm{gpm})$. Another grouting program conducted in 1971 reduced the water inflow to about 0.6 $1 / \mathrm{sec}(9 \mathrm{gpm})$. By 1979 , the inflow had increased to $2.1 \mathrm{l} / \mathrm{sec}(33 \mathrm{gpm})$. PCS, the mine operator, then investigated additional methods to seal off the water. The decision was made to install a cast-iron tubbing section through the water-bearing zone.

The installation of the tubbing liner is described by Tivas (1983) and summarized below. In order to install the cast-iron tubbing without reducing the inside diameter of the shaft, the existing concrete liner had to be partially removed. In the area where the tubbing was to be installed, the original liner thickness was reduced from $50 \mathrm{~cm}(20$ in.) to $10 \mathrm{~cm}(4 \mathrm{in}$.). This was accomplished by drilling about 15,000 40-cm-deep (16-in-deep) holes and using explosives. To reduce the hydrostatic pressure on the liner during this work, 25 old grout holes drilled upwards from a station near the base of the new liner were reopened and allowed to drain about $300 \mathrm{1} / \mathrm{min}(80 \mathrm{gpm})$ of water from the formation.

The concrete removal and cast-iron tubbing installation was done in three lifts from bottom to top. To prevent water pressure building up against the concrete liner during installation of the tubbing, two gravel beds were placed behind the tubbing sections in areas where water penetration was severe. This gravel bed allowed the water to drain out of grout holes that were predrilled in the tubbing. The bottom and top seals consist of pikotage rings with a redundant CSR seal on the top seal. The bottom seal is located at the top of the bottom-most tubbing section. The upper seal is located behind the uppermost tubbing section.

After the tubbing was installed, the two gravel beds were pressure grouted with cement slurry. Several small leaks developed at joints or bolt holes of the tubbing sections. All these leaks were sealed by caulking or tightening of the bolts. The upper seal had a minor leak which was stopped by the injection of cement grout. 


\subsubsection{Erichssegen Shaft}

The Erichssegen Shaft into the Bergmannssegen Huge potash mine in Lower Saxony, Germany, was completed in 1916 with cast-iron tubbing installed to $150 \mathrm{~m}$ (492 ft), $20 \mathrm{~m}$ ( $66 \mathrm{ft}$ ) below the top of salt, and masonry below that to total depth of $580 \mathrm{~m}$ (903 ft). The shaft was sunk in fissured rock to $130 \mathrm{~m}$ $(427 \mathrm{ft})$, where salt was encountered. The lining has apparently leaked since installation. The shaft was grouted numerous times with both cementitious and chemical grouts with limited and short-lived success. The continuing water leaks also contributed to corrosion of the tubbing sections. The operator decided to install a water-tight lining in 1980. The installation of the new liner is described by Stoss and Braun (1983), from which the following summary is taken.

The system chosen for the liner was a steel/concrete composite which was set at $280 \mathrm{~m}(919 \mathrm{ft})$ in competent salt. The composite consisted of a steel liner with an internal reinforced concrete cylinder. The liner was separated from the original lining by an asphalt layer that averaged $0.5 \mathrm{~m}(1.6 \mathrm{ft})$ thick. The new liner was installed on a reinforced concrete foundation ring which was $4 \mathrm{~m}$ tall. A sand-asphalt seal was set on top of the foundation ring to prevent loss of the asphalt seal between the new and old liners. The density of the asphalt was controlled by the amount of powdered limestone added to it and varied from $1.36 \mathrm{~g} / \mathrm{cm}^{3}$ at the bottom of the shaft to $1.12 \mathrm{~g} / \mathrm{cm}^{3}$ at the top.

The new liner was constructed in place. Four sections of formed steel, $4 \mathrm{~m}(13 \mathrm{ft}) \mathrm{high}$, were set in the shaft, welded, inspected, and repaired as necessary. The steel form for the concrete was then set. Ready-mix concrete, transported from the surface in buckets, was poured in $2-\mathrm{m}(7-\mathrm{ft})$ lifts. The asphalt between the two liners was poured as the new concrete liner advanced through the masonry section of the shaft. The asphalt was poured as a unit for the entire tubbing-lined portion of the shaft. Upon completion, the shaft did not leak.

\subsubsection{Cominco Potash Mine \#2 Shaft}

The \#2 Shaft at the Cominco Potash Mine, Saskatchewan, was completed in 1968 into the Prairie Evaporite Formation. In August 1970, during routine grouting in the shaft below cast-iron tubbing installed through the water-bearing zones, one of the grout holes intersected an improperly plugged freeze hole that had been used while sinking the shaft. This resulted in an uncontrollable inflow of water that flooded the entire mine within seven days. The leak in the shaft was eventually plugged through a combination of pumping cement down relief holes drilled from the surface, and injecting grout into a hole drilled into the shaft wall and connected to grout lines run to the surface while the mine was flooding.

The following description is taken from Fredrickson (1983). After dewatering the mine, an extensive grouting program was conducted in the shaft below the tubbing. This grouting reduced leakage into the shaft to about $13.51 / \mathrm{min}$ (3.5 gpm). Additional grouting was conducted in 1975 to repair leaks around 
cold joints. In 1980, a crack developed in the concrete liner, allowing an inflow of about $20 \mathrm{l} / \mathrm{min}$ ( 5 gpm). Drilling to grout this inflow showed that the leak was connected to the overlying Blairmore Formation, which had been the source of the water and sand that flooded the mine in 1970. Cominco decided to extend the cast-iron tubbing across the leak zone. The original tubbing ended just above the leak area. The new tubbing extended from $698 \mathrm{~m}(2290 \mathrm{ft}), 15 \mathrm{~m}(49 \mathrm{ft})$ below the bottom of the freeze

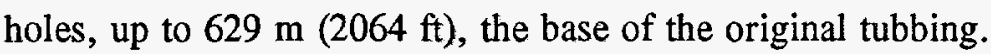

Concrete was stripped from a 7.3-m-high (23.9-ft-high) section of the shaft to allow emplacement of the lower seal. A reinforced concrete foundation and pikotage ring were first built. A CSR seal $1.9 \mathrm{~m}$ $(6.2 \mathrm{ft})$ tall was poured on top of the pikotage. The tubbing was then installed from the bottom up. The annular space between the original concrete lining and the tubbing was filled with a nonshrink grout. The upper seal consisted of CSR poured between the fourth and fifth tubbing sections from the top. The space above the CSR was filled with a nonshrink grout.

About two weeks after completion of the new liner, the grout above the top seal cracked and allowed CSR material and water to extrude. This was repaired by injecting grout above the seal to close the cracks in the original nonshrink grout. The area below the CSR seal was also grouted to improve the tightness of the CSR. When completed, the total leakage through the new tubbing section was about 1 $1 / \mathrm{min}(0.25 \mathrm{gpm})$.

\subsubsection{Willhelmine-Carlsglück Shafts}

Klemme (1979) describes the conversion of an abandoned potash mine in Hülsen, Germany, to a crude oil storage facility. The mine had been active from 1912 until 1924. During World War II, it was reopened and new rooms were driven for a munitions storage site. The mine was closed again from 1949 until 1970.

The shafts were sunk with cast-iron tubbing through the caprock to about $170 \mathrm{~m}(558 \mathrm{ft})$. A reinforced concrete lining was installed below the caprock to about $550 \mathrm{~m}(1805 \mathrm{ft})$ and brick lining to about $600 \mathrm{~m}(1969 \mathrm{ft})$. When the potash operation was abandoned in 1924, the shafts were plugged below the tubbing sections. Neither the plug nor the condition of the shafts after being reopened were described by Klemme (1979) from whom the following is taken.

The shafts were in generally good shape in 1969 when the conversion to oil storage was being planned. About $1,000 \mathrm{~m}^{3}$ of brine was found in the mine near the shafts. This brine was attributed to leakage through the Wilhelmine shaft tubbing. The reinforced concrete lining in the Carlsglück shaft was in generally good shape with minor peeling around $500-\mathrm{m}(1641-\mathrm{ft})$ depth and heavy peeling of the brick lining below $550 \mathrm{~m}(1805 \mathrm{ft})$ due to creep of carnallite. The Wilhelmine Shaft required minor repairs 
to the tubbing, mainly replacement and resealing of bolts, and substantial repairs to the secondary lining of "back-seals and steel rings" in a carnallite region.

\subsubsection{Weeks Island Service Shaft}

The Service Shaft at the SPR site at Weeks Island was developed for a conventional room and pillar salt mine. It was sunk around the turn of the century, and probably completed in 1902. Cast-iron tubbing was installed about $3.1 \mathrm{~m}(10 \mathrm{ft})$ into the salt, and an inner concrete liner was poured to a depth of about $41 \mathrm{~m}(131 \mathrm{ft})$, about $12.9 \mathrm{~m}(41 \mathrm{ft})$ into salt. The concrete liner was sealed against the salt through the use of four asphalt rings evenly spaced $9.4 \mathrm{~m}(30 \mathrm{ft})$ below the tubbing. The asphalt rings were 0.9 to $1.6 \mathrm{~m} \mathrm{(} 3$ to $5 \mathrm{ft}$ ) high and 0.6 to $0.9 \mathrm{~m} \mathrm{(2} \mathrm{to} 3 \mathrm{ft}$ ) thick. Prior to pouring the concrete and asphalt rings, the salt was dried and heated with hand-held torches, and then coated with asphalt. The shaft developed leaks through the tubbing shortly after completion, and two sections of the cast iron required replacement within two years. Other than this, leakage into the shaft was minimal while operated as a salt mine.

After the DOE acquired the mine, some grouting was performed in the shaft through the cement and cement/cast-iron linings in order to stop minor weeps through the liner. Since converting the mine to storage, a persistent drip has developed under the brow of the manifold room near the shaft. This drip, which has reached inflow rates of over $1 \mathrm{l} / \mathrm{hr}$, has been grouted with an acrylate grout on two occasions with short-lived success. After grouting, the leak rate is reduced to about $100 \mathrm{ml} / \mathrm{hr}$, but it increases slowly after a couple of months.

In 1985 and 1986, some cores were taken from the top $22 \mathrm{~m}(70 \mathrm{ft})$ of the concrete lining and adjacent cast-iron tubbing as part of the Risk Abatement Program evaluation of the mine conditions. The cores were analyzed by Geologic Associates and reported in a series of papers (Geologic Associates, $1986 \mathrm{a} ; 1986 \mathrm{~b} ; 1986 \mathrm{c} ; 1986 \mathrm{~d} ; 1986 \mathrm{e})$ to the DOE SPR. The concrete was found to have compressive strengths ranging from 6.8 to $16.8 \mathrm{MPa}(980 \mathrm{psi}$ to $2,430 \mathrm{psi})$ for $1.2-\mathrm{cm}(0.5$-in) cores, and from 12.6 to $69.7 \mathrm{MPa}(1,830 \mathrm{psi}$ to $10,100 \mathrm{psi})$ for $5.7-\mathrm{cm}(2.25$-in) cores. The concrete was described as nonairentrained with natural fine sand aggregate. It had a moderate water-to-cement ratio. All the concrete samples exhibited leaching of the lime matrix and sulfate attack. The sulfate attack has produced widespread microcracking and possible "incipient deterioration due to alkali-silica reaction" (Geologic Associates, 1986b). The samples of the cast iron were in good shape with minimal corrosion of less than $1.6 \mathrm{~mm}(1 / 16-i n)$ penetration. 


\subsubsection{WIPP Shafts}

The four shafts at the WIPP site are lined through the Rustler Formation and keyed into the upper Salado Salt Formation. Three of the shafts liners are concrete and the salt handling shaft is steel. The geologic section comprises mudstone, anhydrite, sandstone, and dolomite. Other than the Culebra, which is commonly called a "water-bearing unit," limited groundwater is encountered in the stratigraphy. Grouting has been active at the WIPP site since 1981, when the salt handling shaft was first grouted. Grouting has been periodic in all four shafts over the ensuing years. Both cement grouts and chemical grouts have been applied multiple times. Despite grout remediation, inflow of small amounts of brine has been evident over the years, as wet spots, drips, tell-tale rock flower or degraded concrete on construction joints.

\subsection{Shaft Plugging in Salt}

In the United States, upon mine abandonment, most shafts are plugged in accordance with Mine Safety and Health Administration (MSHA) regulations, which require that the shaft collar be covered with a solid bulkhead to prevent people and animals from falling into the shaft. There is no requirement, nor are attempts generally made, to seal a shaft to eliminate fluid movement.

\subsubsection{Jefferson Island Sealed Air Shaft}

An air shaft into Diamond Crystal Salt Company's Jefferson Island (Louisiana) salt mine was found to be leaking in March 1975. To avoid damage to the mine, the shaft was plugged. The shaft was about

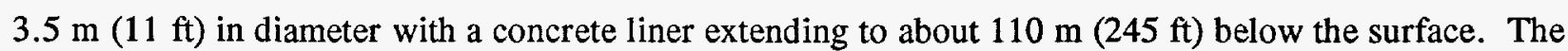
shaft was $278.6 \mathrm{~m}(877 \mathrm{ft})$ deep and bottomed in a room within the mine. Mine Safety and Health Administration (1981) contains a brief description of the plugging, and the following account is taken from that report. Plugging consisted of filling the bottom of the shaft to about $-265 \mathrm{~m}(-834 \mathrm{ft})$ with mine-run salt. This was topped with $3.1 \mathrm{~m}(10 \mathrm{ft})$ of high-early-strength concrete. From the top of this

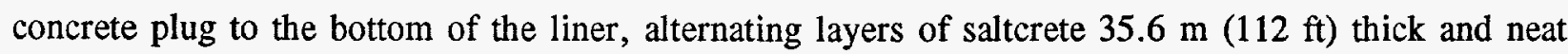
cement $3.1 \mathrm{~m}(10 \mathrm{ft})$ thick were placed. The last layer of neat cement was from $-110 \mathrm{~m}$ to $-101 \mathrm{~m}(-346$ $\mathrm{ft}$ to $-318 \mathrm{ft}$ ). The remainder of the shaft was filled with a heavy (approximately $22 \mathrm{lb} / \mathrm{gal}$ ) drilling mud above that point. All the material was placed in the shaft by dumping it from the collar. All the

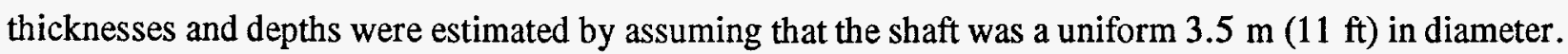
Sealing of the shaft was completed in March 1975. 
The Jefferson Island Mine flooded when a drillhole penetrated another part of the mine on November 20,1980 . The shaft bottom was checked during the evacuation from the mine to determine if it had been the source of the water intrusion. There was absolutely no indication of leakage through the plugged shaft (Mine Safety and Health Administration, 1981).

\subsubsection{Patience Lake (PCA)}

The Potash Corporation of America (PCA) Mine near Saskatoon, Saskatchewan, was flooded by a water inflow from overlying sediments in 1986. Because of the large inflow rate, the company decided to abandon the mine as a conventional potash mine. As a part of the abandonment, both shafts were plugged above the salt/potash horizon. Smith (1988) describes the concrete plugs as $15.9 \mathrm{~m}$ (50 ft) long and placed within a limestone $47.6 \mathrm{~m}(150 \mathrm{ft})$ above the working level. These plugs had withstood the water pressure of approximately $10 \mathrm{MPa}$ from below for over one year at the time Smith reported on the mine. The mine was subsequently converted to a solution-mining operation for the recovery of potash.

\subsubsection{Retsof Sterling "C" Shaft}

The Sterling Mine is connected underground to the AKZO Nobel Salt Company's Retsof Mine near Geneseo, New York. An uncontrollable inflow began into the Retsof Mine in March 1994, and the entire underground complex will be flooded by the fall of 1996. The Sterling "C" Shaft was sealed (filled) while underground access was still available. This shaft was originally constructed around 1908, and was unlined except for wood lagging. Prior to the shaft filling, bulkheads were built in drifts connected to the shaft bottom to contain the concrete slurry.

The shaft was filled with a fly ash/cement mixture dumped from ready-mix trucks at the shaft collar and allowed to free fall down the shaft. The cement slurry was mixed thin so that it could more easily fill the space behind the wood lagging in the shaft. Sections of the wood lagging were removed to allow the cement to fill the void between the lagging and the rock wall. The slurry was placed in stages (lifts) to allow the preceding stage to harden, particularly while filling the shaft bottom to minimize the pressure on the bulkheads in the drifts. The nominally 318 -m-deep (1,000-ft-deep) shaft was plugged during a period of about four weeks.

Three different mixes were used: (1) a high-cement mix at the shaft bottom (7.8 MPa, 28-day strength), (2) a somewhat weaker mix (less cement) across the potential water-bearing zones at about 190 to $222 \mathrm{~m}$ (600 to $700 \mathrm{ft}$ ) (3.4 MPa at 28 days), and (3) a still weaker mix between the water-bearing zones and the top of the shaft $(0.7 \mathrm{MPa}, 28$-day strength). Fresh water was added to achieve about 10 -in (25-cm) slump of the mix. The intermediate mix had permeability of $8\left(10^{-6}\right) \mathrm{cm} / \mathrm{s} \approx 10^{-13} \mathrm{~m}^{2}$. 


\subsection{CONCLUDING REMARKS}

The original intent of this investigation was to obtain information about the experiences within the salt and potash mining industries in designing and building seals. After contacting representatives of some 30 mines, it was determined that the bulkheads known to the investigators beforehand represented all the bulkheads built to date in North American salt and potash mines.

Bulkheads of interest have been built in three mines: the IMC K2 and PCS Rocanville potash mines in Saskatchewan, and the Weeks Island SPR oil storage facility in Louisiana. Of these, the Rocanville bulkhead has been an unqualified success. The Rocanville bulkhead is built in halite (because of a geological anomaly), even though it is in a potash mine. The design and construction of the bulkhead took only a few weeks, and the conditions for the construction were less than ideal. Despite these factors, the bulkhead has resisted water pressures approaching $10 \mathrm{MPa}$ for the past 10 years. The Rocanville bulkhead is a stellar example of sealing success in salt.

The IMC bulkheads are basically untested. Three of the bulkheads were for water control as portions of the mine flooded. These bulkheads (more appropriately called dams) served to hold back water, but they were only tested once, and then only under minimal water levels for a short time. These dams did, however, demonstrate that the DRZ can be cured by a stiff emplacement in an opening subject to rapid creep. A fourth IMC bulkhead, which was installed as a precaution against cemented-casing failure for a borehole penetrating the mine, has not been tested. The "bulkhead test" was not a successful demonstration of bulkhead technology. It is evident that IMC made a concerted effort to design an appropriate test, but construction problems apparently prevented successful completion. The test site may still be a cost-effective research area for measuring full-scale, long-term (currently eight-year) concrete seal behavior. It is important to recognize that the bulkheads are located in the potash-ore zone rather than pure halite, the bulkheads are located in areas of much greater extraction than at the WIPP site, and the installations are horizontal.

The Weeks Island bulkheads provide true analogs for bulkheads designed and built full-scale under government contracts. The successes of these bulkheads have been mixed. Repairs or supplemental construction have been required to achieve tight seals on some bulkheads. On others, even remediation has not been successful. These bulkheads may provide an opportunity for access and field measurements because the Weeks Island SPR facility is being abandoned. Previous concerns about coring and testing the bulkheads when the facility contained oil will be abated. The opportunity for access and field measurements may be of short duration because the mine is to be flooded after oil withdrawal.

The information available to the authors about the bulkhead test in the Hope Mine (Germany) was insufficient to determine what lessons can be learned from the test. Preliminary information indicates that the postflooding measurements would be useful for comparison to possible scenarios at the WIPP. 
A closer connection with the German repository sealing program is required to obtain the required information.

Shaft liners are not an extremely close analog to bulkheads constructed in salt that is essentially dry. The liners are constructed in a different fashion than bulkheads and, for the most part, are placed through nonsalt rocks overlying the salt formation that are penetrated by the shafts. Emphasis in shaft construction is control of unconsolidated ground and restricting active water inflows. The shaft liners typically develop leaks of some magnitude. The leaks generally occur at construction joints. In areas with major aquifers, the leaks require active grouting programs to seal them off. Even with grouting, the shafts often require relining in order to isolate the mine from the overlying aquifers. Techniques used to construct shaft liners, particularly the placement of water-sealing materials on the outside of the liners, may provide some insight about methods that would be applicable to seals between the rock salt and bulkheads.

An insufficient amount of information on shafts plugging is available to provide useful and definitive comparisons between shaft plugging and abandonment and bulkheads in salt. The small amount of available information discussed in the text indicates that concrete plugs in mine shafts have sealed the shafts for a period of about 10 years.

This study of seal analogs was undertaken with the intention that the WIPP seals program could learn from both the successes and failures of sealing programs performed in North America's salt and potash mines. Sealing programs that were failures are potential sources for learning from the mistakes of others, although this implies a good understanding of the root causes of the failures. On the other hand, successful sealing programs provide indications of what might also be successful at WIPP, but the successful programs must be studied in sufficient detail to determine influential differences in the design life and requirements, the materials used (or available), the rock around the seals, and the fluids involved.

Assessments made by the authors, based on the case studies reviewed in this report, include the following:

1. Seals in salt and potash mines can be successfully built using concrete as the primary material. Ten years of successful sealing against a full hydrostatic head of brine by the Rocanville bulkhead is the most obvious example. The Rocanville bulkhead also demonstrates that a simple frame-up construction technique with post-emplacement grouting is a viable construction method.

2. The bulkhead demonstration at IMC/Esterhazy was unsuccessful primarily for reasons unrelated to the design or construction of the main full-scale bulkhead. The leakage through the DRZ surrounding the bulkhead was mostly through the potash ore (carnallite and sylvite comprised 40 percent of the salt rock). The IMC experiences with frame-up construction corroborates the 
Rocanville bulkhead experience. The IMC experience also demonstrated that "shotcrete-style" construction produces a concrete with too much porosity and material segregation for seal attainment.

3. Construction practices for concrete placements are fairly mature and straightforward. Full-scale bulkheads have been constructed at Rocanville, IMC, and Weeks Island. The use of additives for set retardation and slump control are less scientific and, according to contractors' rules-ofthumbs, they may be desirable from a quality assurance viewpoint; however, very large volumes of concrete have been placed in situ and appear to be functional.

4. Jefferson Island provides the only incontrovertible example of a successful shaft seal in salt over a multiple-year time frame. Other sealed shafts lack the access required to determine their tightness. 


\subsection{REFERENCES}

Ahrens, A.H. and F. D. Hansen. 1995. Dynamic Compaction of WIPP Salt: Fielding and Preliminary Results. SAND95-1941. Albuquerque, NM: Sandia National Laboratories.

Blanford, M.L., D. Segalman, and R.L. Parrish. 1990. Strength Analyses of the Weeks Island Bulkheads. SAND90-0013. Albuquerque, NM: Sandia National Laboratories.

Cleasby, J.V., G.E. Pearse, M. Grieves, and G. Thorburn. 1975. "Shaft Sinking at Boulby Mine, Cleveland Potash, Ltd," Transactions of the Institute for Mining and Metallurgy, Section A. Vol. 84 , no. 818, A7-A28.

Ehgartner, B. 1991. Summary of Characterization Tests on a Low Density Epoxy Grout for Use as a Bulkhead Seal Material in US Strategic Petroleum Reserve. SAND91-1112. Albuquerque, NM: Sandia National Laboratories.

Fischle, W.R., and W.H. Stöver. 1986. Construction of a Bulkhead and Measurement under Brine Pressure. Presented at the Solution Mining Research Institute, Amsterdam, September 21-24.

Fredrickson, H.K. 1983. "Installation of a Second Tubbing Lining in \#2 Shaft of Cominco Potash," Potash Technology, Proceedings of the 1st International Conference, Saskatoon, Saskatchewan, October 3-5, 1983. Ed. R.M. McKercher. New York, NY: Pergamon Press. 389-394.

Geologic Associates, Inc. 1986a. Report of Initial Preliminary Study, Strategic Petroleum Reserve, Concrete Evaluation, Weeks Island, Louisiana. GA File 85-0448FA. (Copy on file at Sandia WIPP Central Files, Sandia National Laboratories, Albuquerque, NM.)

Geologic Associates, Inc. 1986b. Concrete (Grout) Core Evaluation Number 2, Strategic Petroleum Reserve, Weeks Island, Louisiana. GA Project 86-201F. (Copy on file at Sandia WIPP Central Files, Sandia National Laboratories, Albuquerque, NM.)

Geologic Associates, Inc. 1986c. Report of Initial Preliminary Study, Metal Core Evaluation, Strategic Petroleum Reserve, Weeks Island, Louisiana. GA Project No. 86-201F. (Copy on file at Sandia WIPP Central Files, Sandia National Laboratories, Albuquerque, NM.)

Geologic Associates, Inc. 1986d. Metal Core Evaluation Number 2, Strategic Petroleum Reserve, Weeks Island, Louisiana. GA Project No. 86-201F. (Copy on file at Sandia WIPP Central Files, Sandia National Laboratories, Albuquerque, NM.) 
Geologic Associates, Inc. 1986e. Metal Bolt Failure Evaluation, Strategic Petroleum Reserve, Weeks Island, Louisiana. GA Project No. 86-201F. (Copy on file at Sandia WIPP Central Files, Sandia National Laboratories, Albuquerque, NM.)

Hart, D.E., and J. Fallis. 1993. "Extension of a Concrete Shaft Lining at the Cote Blanche Mine Louisiana, USA," Seventh Symposium on Salt, Kyoto, Japan, April 6-9, 1992. Eds. H. Kakihana, H.R. Hardy, Jr., T. Hoshi, and K. Toyokura. New York, NY: Elsevier. Vol. 1, 285-291.

Herbert, H.J., and W.H. Stöver. 1985. "Research Work During and After the Flooding of an Abandoned Potash Mine in Northern Germany," High-Level Nuclear Waste Disposal, International Topical Meeting, Pasco, WA, September 24, 1985. Ed. H.C. Burkholder. Columbus, OH: Battelle Press. 499-510.

Herbert, H.J., and W.H. Stöver. 1986. "Geochemical, Geomechanical and Geophysical Measurements and Testing of an Underground Dam During the Flooding of a Salt Mine," International Symposium on Siting, Design and Construction of Underground Repositories for Radioactive Wastes, Hannover, West Germany, March 3-7, 1986. Vienna, Austria: International Atomic Energy Agency. 637-651.

Jacobs Engineering Group. 1988a. Conceptual Design Report for Markel Isolation Bulkheads. Contract DE-AC96-88P080000, Task WI-1004. Prepared for Department of Energy.

Jacobs Engineering Group, Inc. 1988b. Weeks Island Risk Abatement Program, Conceptual Design Report for Bulkhead Upgrades. Rev. 0. Prepared for U.S. Department of Energy, Strategic Petroleum Reserve for Jacobs Engineering Group, Inc. (Copy on file at the Sandia WIPP Central Files, Sandia National Laboratories, Albuquerque, NM.)

Jacobs Engineering Group, Inc. 1989a. Weeks Island Risk Abatement Program, Confirmatory Tests at Number 1 Borehole. Prepared for U.S. Department of Energy, Strategic Petroleum Reserve by Jacobs Engineering Group, Inc. (Copy on file at the Sandia WIPP Central Files, Sandia National Laboratories, Albuquerque, NM.)

Jacobs Engineering Group, Inc. 1989b. Weeks Island Risk Abatement Program, Field Test Report. Prepared for U.S. Department of Energy, Strategic Petroleum Reserve by Jacobs Engineering Group, Inc. (Copy on file at the Sandia WIPP Central Files, Sandia National Laboratories, Albuquerque, NM.)

Jacobs Engineering Group, Inc. 1990a. Strength Analysis of the Weeks Island Bulkheads. Contract DEAC96-88P080000, Task WI-1003. Letter report prepared for U.S. Department of Energy, JEG Ref. 58-A821-179. 
Jacobs Engineering Group, Inc. 1990b. Conceptual Design Report Addendum for Bulkhead Upgrades Layered Plug Concept. Prepared for U.S. Department of Energy, Strategic Petroleum Reserve, Project Management Office by Jacobs Engineering Group, Inc. (Copy on file at the Sandia WIPP Central Files, Sandia National Laboratories, Albuquerque, NM.)

Klemme, J. 1979. "The Conversion of the Abandoned Potash Mine 'Wilhelmine-Carlsgluck' in Hulsen/Verden, West Germany, to Crude Oil Storage," In Situ. Vol. 3, no. 2, 121-146.

Mine Safety and Health Administration. 1981. The Jefferson Island Mine Inundation. Arlington, VA: U.S. Department of Labor, Mine Safety and Health Administration.

Nowak, E.J., J.R. Tillerson, and T.M. Torres. 1990. Initial Reference Seal System Design: Waste Isolation Pilot Plant. SAND90-0355. Albuquerque, NM: Sandia National Laboratories.

Oellers, T. 1983. "Asphalt - An Active Sealing Medium for Shaft Construction." Glückauf: Zeitschrift für Technik und Wirtschaft des Bergbaus. Vol. 119, no. 12, 567-570. (Copy on file at the Sandia WIPP Central Files, Sandia National Laboratories, Albuquerque, NM.)

PB-KBB Inc. 1982. Overview of Underground Construction Weeks Island Storage Site New Iberia, Louisiana. Prepared for Petroleum Operations and Support Services, Inc. for Department of Energy, Strategic Petroleum Reserve Program. (Copy on file at the Sandia WIPP Central Files, Sandia National Laboratories, Albuquerque, NM.)

Prugger, F.F., and A.F. Prugger. 1991. "Water Problems in Saskatchewan Potash Mining - What Can be Learned From Them?" CIM Bulletin. Vol 84, no. 945, 58-66.

Pusch, R. 1979. "Highly Compacted Sodium Bentonite for Isolating Rock-Deposited Radioactive Waste Products." Nuclear Technology. Vol. 45, 153-157.

S-Cubed. 1985. "Compressed Air/Tracer Gas Test at the Weeks Island SPR Site." SSS-R-86-7620. Prepared for Boeing Petroleum Services. (Copy on file at the Sandia WIPP Central Files, Sandia National Laboratories, Albuquerque, NM.)

Sitz, P. 1982. "Calculation and Design of Underground Dams With Special Reference to Their Use in Rock-Salt," First International Mine Water Congress of the International Mine Water Association, Budapest, Hungary, April 19-22, 1982. Budapest: Hungarian Mining and Metallurgical Society. 69-87.

Sitz, P., V. Koeckritz, and T. Oellers. 1989. Shaft Sealing for Nuclear Waste Repositories. London: Institution of Mining and Metallurgy. 345-352. 
Slagle, K.A., and D.K. Smith. 1963. "Salt Cement for Shale and Bentonitic Sands," Journal of Petroleum Technology. Vol. 15, 187-194.

Smith, D.K. 1990. Cementing. Monograph 4. Richardson, TX: Society of Petroleum Engineers.

Smith, R.C. 1988. "The Conversion of a Flooded Potash Mine to a Solution Mine (Turning a Lemon into Lemonade)," Presented to the Raw Materials Meeting International Fertilizer Industry Association, Phoenix, AZ, September 22, 1988. (Copy on file at the Sandia WIPP Central Files, Sandia National Laboratories, Albuquerque, NM.)

Stormont, J.C. 1984. Plugging and Sealing Program for the Waste Isolation Pilot Plant (WIPP). SAND84-1057. Albuquerque, NM: Sandia National Laboratories.

Stormont, J.C. 1988. Preliminary Seal Design Evaluation for the Waste Isolation Pilot Plant. SAND873083. Albuquerque, NM: Sandia National Laboratories.

Stormont, J.C., and J.G. Argüello. 1988. Model Calculations of Flow Through Shaft Seals in the Rustler Formation. SAND87-2859.. Albuquerque, NM: Sandia National Laboratories.

Stoss, K., and B. Braun. 1983. "Installation of a Watertight Lining to Secure a Leaking Salt Shaft," Potash Technology, Proceedings of the 1st International Conference, Saskatoon, Saskatchewan, October 3-5, 1983. Ed. R.M. McKercher. New York, NY: Pergamon Press. 377-382.

Thomas, O. 1957. "Sealing Shafts with Bitumen." Bergbautechnik. Vol. 7, no. 2, 90-94. Translated by M.L. Steve for Office of Nuclear Waste Isolation, Battelle Memorial Institute, Columbus, OH. (Copy on file at the Sandia WIPP Central Files, Sandia National Laboratories, Albuquerque, NM.)

Tivas, H.A. 1983. "Installation of a Tubbing Column in Shaft \#1 of the Allan Potash Mine," Potash Technology, Proceedings of the 1st International Conference, Saskatoon, Saskatchewan, October 3-5, 1983. Ed. R.M. McKercher. New York, NY: Pergamon Press. 357-361.

Valk, J. 1989. "Watertight Lining Systems to Secure Leaking Shafts." Transactions of the Institution of Mining and Metallurgy, Section A. Vol. 98, A137-A143.

Van Sambeek, L.L., D.D. Luo, M.S. Lin, W. Ostrowski, and D. Oyenuga. 1993. Seal Design Alternatives Study. SAND92-7340. Albuquerque, NM: Sandia National Laboratories.

Wakeley, L.D., P.T. Harrington, and C.A. Weiss, Jr. 1993. Properties of Salt-Saturated Concrete and Grout after Six Years In Situ at the Waste Isolation Pilot Plant. SAND93-7019. Albuquerque, NM: Sandia National Laboratories. 
APPENDIX A

CANADIAN MINES FIELD TRIP REPORT

A-1 


$$
\text { A-2 }
$$




\section{Technical Memorandum}

To:
Mr. Al W. Dennis
Sandia National Laboratories
Department 6121
P.O. Box 5800
Albuquerque, NM 87110-5800
ce: Dr. D. E. Munson, Sandia Nationai Laboratories 325/7 Task File

From: Dr. Leo L. Van Sambeek RE/SPEC Inc. P.O. Box 725 Rapid City, SD 57709

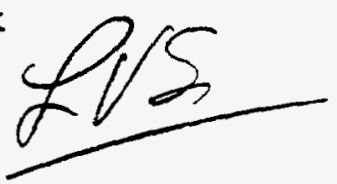

Dr. Frank D. Hansen Sandia National Laboratories

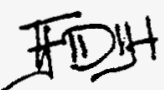

Division 6121

P.O. Box 725

Albuquerque, NM 87185

Date: July 25, 1994

Subject: Canadian Trip

\section{ROCANVILLE POTASH MINE TRIP REPORT}

On Juiy 6, 1994, Frank D. Hansen and Darreil E. Munson, Deparwment 6121 of Sandia National Laboratories (SNL), and Leo L. Van Sambeek, RE/SPEC Inc., visited the PCSRocanville potash mine. Of particular interest was an underground bulkhead installed in January 1985 to block brine inflow into the mine. Mr. Jim Lewis, Mine Superintendent, hosted the visit, conducted the underground tour, and answered many questions about the bulkhead and the mine in generai. This report documents our observations and general facts obtained during the visit. 


\section{BACKGROUND}

The mine was originally developed by Hudson Bay Mining and Smeiting in 1970. In about 1978, Rocanville, along with several potash mines in Saskatchewan. was taken over by Potash Corporation of Saskatchewan, a crown corporation. Sometime in the late-80's or early 90's, the crown corporation was privatized with a saie of stock.

The shafts at Rocanville were sunk with a 20 -ft diameter and were subsequently lined to a 16-ft finished diameter. Both concrete (it is unknown if the shaft concrete is salt-saturated or not) and cast-iron tubbing were used. The cast-iron tubbing was used over four waterbearing intervals: believed to be the Blairmore, Bakken, Nisku, and Dawson Bay Formations. The concrete lining was extended beyond the potash level (at 3,150 ft) to a total depth of about $3,500 \mathrm{ft}$. The concrete liner was then cut to open into the potash interval.

The ore is a mixture of halite ( 60 percent), syivite ( 33 percent), and carnallite ( 7 percent). Usually the minerals are mixed heterogeneously, and the carnallite content can increase to 20 percent. Carnallite also appears in massive pods - tens of $\mathrm{ft}$ in length and up to $5 \mathrm{ft}$ thick. The distributed carnallite is typically iron-stained (red-orange) while the pods contain white carnallite. The sylvite is contained in beds of varying concentration. The ore horizon is tracked during mining using electronic (gamma ray) sensors to follow its gentle undulations.

Mining is performed with four-rotor Marietta miners. A single pass of the miner creates a room 26-ft wide. Two and three passes expand the rooms to $46 \mathrm{ft}$ and $65 \mathrm{ft}$, respectively. Travelways are normally two passes wide and production rooms three passes wide. The mining height is a uniform $8 \mathrm{ft}$ except in special areas where an alpine miner (road header) is used to increase the height. In the parallel production rooms, a single pass is extended $6,000 \mathrm{ft}$ as conveyor is installed. At the end of the room, the miner is turned around and a reverse pass is made from the right-hand side. A conveyor bridge is used to feed the ore onto the conveyor. When the original end of the room is reached, the miner is again turned around and another pass is mined, again from the right-hand side. When the miner reaches the far end, the room is complete and the miner moves on to the next room. The conveyor is recovered while the next room is mined. Each room requires 1 month to mine (two $12-h r$ shifts per day, 61/2 days per week) and produces 150,000 tons of ore. Thus far, over 450 miles of such rooms have been mined. The pillar width between rooms is $90 \mathrm{ft}$ leading to an extraction ratio of 42 percent. The nameplate capacity of the mine is 6 millions tons per year, but demand restricts production to about 60 percent of capacity.

\section{WATER PROBLEM}

Water, which originated from the overiying Dawson Bay Formation, began to flow into the mine from the floor of a singie pass room being driven through a solution collapse structure. The collapse structure resulted from dissolution of sylvite and carnallite from the Prairie Evaporite and subsequent collapse (slumping) of the Prairie Evaporite into the void. At the mining horizon, a collapse structure appears as barren salt. Water began to enter the room 
after about a 400-ft penetration into the barren salt. The flow was initially slow but increased to $5,000 \mathrm{gpm}$ as the flowpath was apparently widened by dissolution. The Dawson Bay brine is undersaturated in halite by about 0.1 pounds per gallon and is virtually barren in potassium and magnesium, based on sampling at the IMC Mine, which is identically situated in the stratigraphy.

\section{BULKHEAD}

A concrete bulkhead was designed to contain the inflow and prevent additional inflow into the mine. The bulkhead was designed to consist of a "temporary" bulkhead located $120 \mathrm{ft}$ from the face (point of inflow) and a permanent bulkhead with a 43 -ft interval between them. Only the temporary bulkhead was installed because it proved to be tight and completely capable of squelching the inflow. The "temporary" bulkhead has functioned perfectly since its emplacement in 1985/86. Dates of construction are noted on Figure 1, which is a cross-sectional view of the bulkhead.

The bulkhead consists of five concrete segments. Construction was expeditious. Inflow initiated in November 1985, and construction of the first 8-ft-thick cofferdam was finished on December 16. A 70-ft opening was left between the cofferdam and the second 8-ft concrete segment for later mass placement of concrete which would be purnped through the entire bulkhead. In anticipation of the massive pour of concrete at a later date, concrete blocks were tossed in a pile in the 70 -ft section to reduce volume of concrete needed to fill the void, thus reducing heat of hydration. Two chemical seal rings were also placed, as sketched in Figure 1. The construction schedule should be noted. The third monolith of about $16 \mathrm{ft}$ was finished 4 days (on January 8) after the previous section (January 4). The fifth segment was keyed into the salt to resist thrust from pressurized water on the bulkhead face. The 87 -ft-long concrete installation was started on January 4 and completed on January 28, 1985; a remarkable achievement considering the circumstances.

The forms for the concrete were apparently wood timbers, faced with plywood and covered with burlap. The burlap covering prevented seepage through the construction cracks and provided a roughened face that could be rapidly prepared for the next cast of concrete. Edges of the forms were filled with hand-cut plywood and stuffed with burlap as necessary during placement. Various pipes for concrete placement, interface grouting, chemical seal ring injection, and water pumping were installed through the forms. (The face of the bulkhead reveals about 100 pipes and tubes of various diameter ranging from $0.5 \mathrm{in}$. to $8 \mathrm{in}$.). One bundle of instrument cables (five) was also noted. All concrete was pumped into the forms from an underground batch plant.

Cement was brought into the mine in "supersacks" and fly ash in paper sacks. Bentonite was also brought in but apparently was not used. Aggregate is crushed granite of nominally 3/4-in diameter and smaller. Mr. Lewis was uncertain if the inflowing brine or freshwater was used for mixing the concrete. Mr. Lewis thought the cement was Type 10 (Canadian standard). The appearance of the bulkhead face is solid showing no evidence of cracking or distress whatsoever. There appears to have been minor leakage along the instrument-lead bundle 


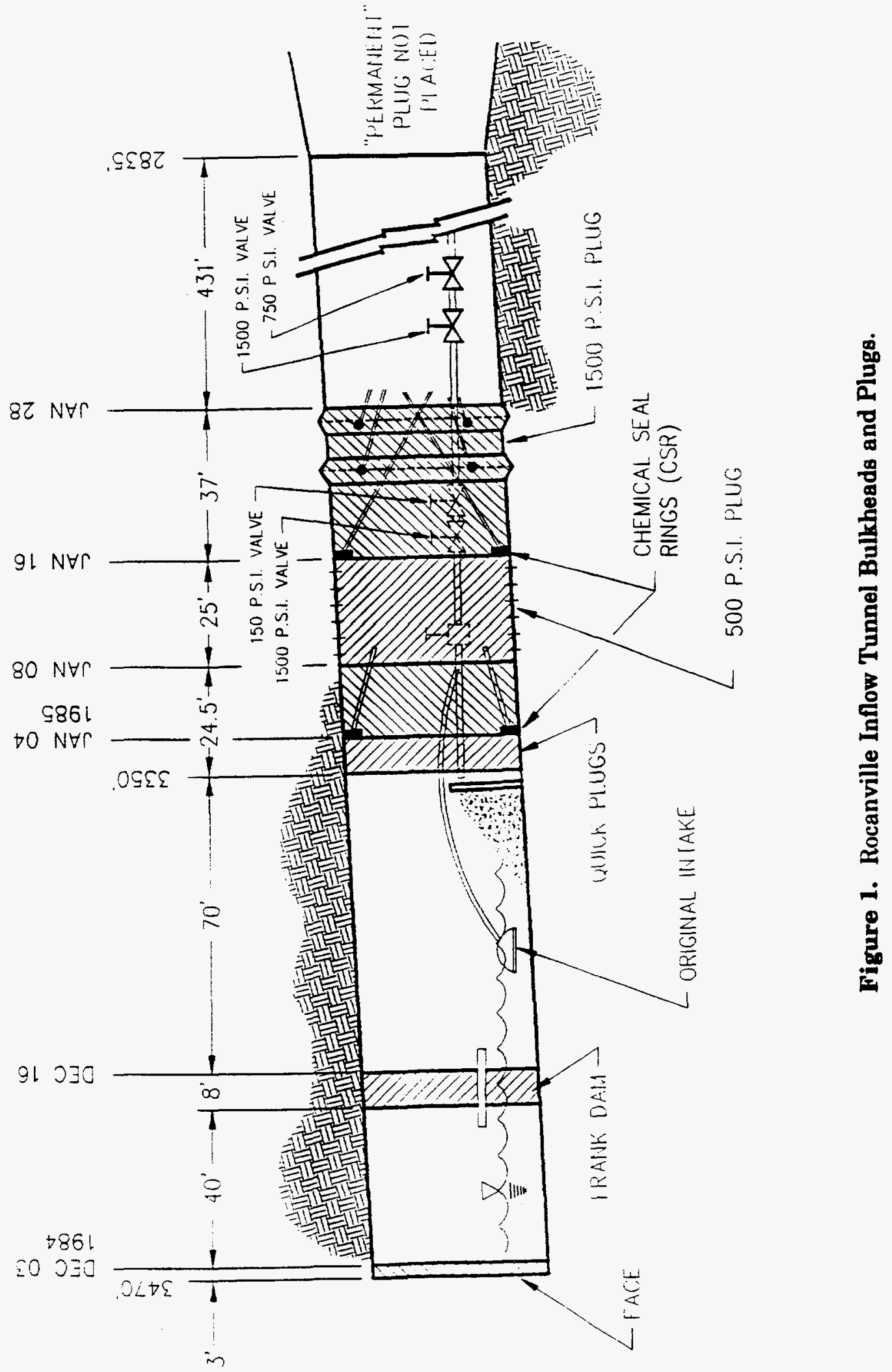


(piezometers) evidenced by encrusting salt precipitate. There is no evidence whatsoever of leakage along any of the 100 pipes and tubes. The roof interface is apparently tight and observations suggest the tightness existed from construction practice. not subsequent squeeze. This conclusion is based on the existence yet today of some "ooze" of concrete over the top form plank through slightly high spots in the roof (cutter tooth marks).

The brine pressure in various pipes passing through the bulkhead is 1,000 to $1,375 \mathrm{psi}$, approximately full hydrostatic head. According to Mr. Lewis, the brine pressure can be greatly reduced by small, rapidly diminishing, discharges of brine from the pipes, but upon closing eventually the pressure rebuilds to the same hydrostatic pressures as before release.

Rocanville personnel were most cooperative and responsive to our questions. They expressed a willingness to cooperate with Sandia National Laboratories to the extent they can. Currently the Rocanville Mine is invoived in active legal proceedings regarding the brine inflow, which prompted the construction of the bulkhead. Therefore, the amount of information readily available will be limited until clarification is achieved on the legal issues. We may address future inquiry to Garth Moore, PCS Vice President of Technical Services (306-933-8500).

Attached to this memorandum is a 6-page description of the Potash Corporation of Saskatchewan, Inc. It includes figures of the mine layout and a stratigraphic column.

\section{IMC POTASH MINE TRIP REPORT}

On July 7, 1994, Darrell E. Munson and Frank D. Hansen of Department 6121, Sandia National Laboratories (SNL), and Leo L. Van Sambeek, RE/SPEC Inc. visited the International Chemical and Mineral (IMC) Corporation's K2 Mine near Esterhazy, Saskatchewan. IMC personnel involved in the visit included: Mr. Martin Reading (306-745-5268), Engineering, Construction. and Water Recovery Superintendent, who gave a brief overview of mine operations emphasizing water problems; Mr. Bob Morgan (745-5340), Water Recovery Manager, who led the tour of the underground; Mr. Bob Hartl (745-5357) and Brian Stronach (745-5307), engineers who developed the concrete and helped emplace bulkheads; and John Unrau (745-5202), a rock mechanics engineer.

The purpose of the site visit was to open dialogue between IMC engineers who have placed concrete bulkheads in an evaporite medium and SNL technical personnel involved with design of WIPP seais. The WIPP program has a need to establish credibility for the use of concrete for seal components at the WIPP. IMC has placed four operational concrete bulkheads for water control, as well as two experimental buikheads. We toured the underground in the morning and held further discussions in the conference room in the afternoon. The text below loosely follows the events of the day. 


\section{BULKHEADS}

The bulkheads in the $\mathrm{K2}$ Mine are identified as three "D-Block entry" dams installed in early 1986, the BFI buikhead installed in eariy 1987, and the B512 test bulkheads (believed to have been installed in mid to late 1987). The locations of the bulkheads are shown in Figure 2, which is a drawing of part of the IMC K2 Mine. All concrete for these bulkheadis was batched underground using fresh water.

The first D-Block dam visited is located in the D400 entry of the underground workings (about 3,150 feet underground). It is $98 \mathrm{in}$. thick and has a tapering width from 56.8 to 63.8 $\mathrm{ft}$. The tapering height is 7.9 to $11.2 \mathrm{ft}$. The bulkhead was shaped as a wedge (tapered) to counteract possible thrust from water pressure. A vehicle passageway has been drilled and blasted through it subsequent to its emplacement. The blasted entry allowed inspection of both sides of the concrete and its interior. Some blast-induced fracturing is evident along the passageway. The crown is tight at the concrete/salt interface. Grout pipes extend out the front face and small amounts of concrete spalling (called "popping" by Van Sambeek) around the pipes is noticeable. In an attempt to better seal the DRZ, a polyurethane coating was sprayed over the face of the bulkhead and the surface of salt for about $50 \mathrm{ft}$ down stream. One-inch-diameter rebar was used as form ties, but there was apparently no other reinforcement. Concrete was placed through four concrete pipes near the crown. The lower portion was vibrated by men in the form, and the upper portion apparently was pressurized but was not vibrated.

The dam in Entry D500, another of the D-Block group, was also covered with polyurethane, which was cracked slightly near the roofline. A pipe (about 18 in. diameter) was cast in the D500 bulkhead to provide for pumping behind the dam. The D500 dam tapered from 35.6 to $45.0 \mathrm{ft}$ in width with a minimum height of $7.6 \mathrm{ft}$. The dam in Entry D300, which was viewed only on the upstream side (east), contains 80 cyd of concrete that was pumped $800 \mathrm{ft}$ and placed in a $12-\mathrm{hr}$ shift, including cleanup. The underground batch plant used a spirai auger (two reverse blades) for mixing. The $\mathrm{D} 300$ and $\mathrm{D} 500$ bulkheads are similar in size as they are both in the 4-pass-wide entry. (That is, $13 \mathrm{ft}$ of width for the first pass of the miner and $8 \mathrm{ft}$ for each subsequent pass, a total of four passes, thus producing an entry about $37 \mathrm{ft}$ wide).

The BF1 bulkhead was built in the 08B052 entry, which was mined in early 1987 to intercept a backfill borehole drilled and cased from the surface. The bulkhead was a safety precaution against water entry to the mines if the casing cement job had been inadequate. The bulkhead was viewed from a distance because of standing water. Its size is about $20+\mathrm{ft}$ wide, $8-10 \mathrm{ft}$ thick, and $8 \mathrm{ft}$ tall. The concrete is penetrated by the backfill pipe and a man-door. The steel liner in the man-door is warped from the deformation of the concrete. The face of the bulkhead is spalling, but only to depths of an inch or two.

The 512 bulkhead test is a partially completed experiment conducted by IMC and PCS. The arrangement of the test was to have involved three bulkheads as shown in Figure 3, but only two were placed. The test was to demonstrate that the DRZ surrounding mined rooms could be seaied using a combination of two concrete dams and an over-pressurized interval between them. The idea is that if a head of brine is downstream from the first concrete dam and a fluid (less dense than the brine; say, diesel) is pressurized above the brine, it will prevent flow along 
Technical Memorandum

RSI-325-94-053
Page 7

July 25, 1994

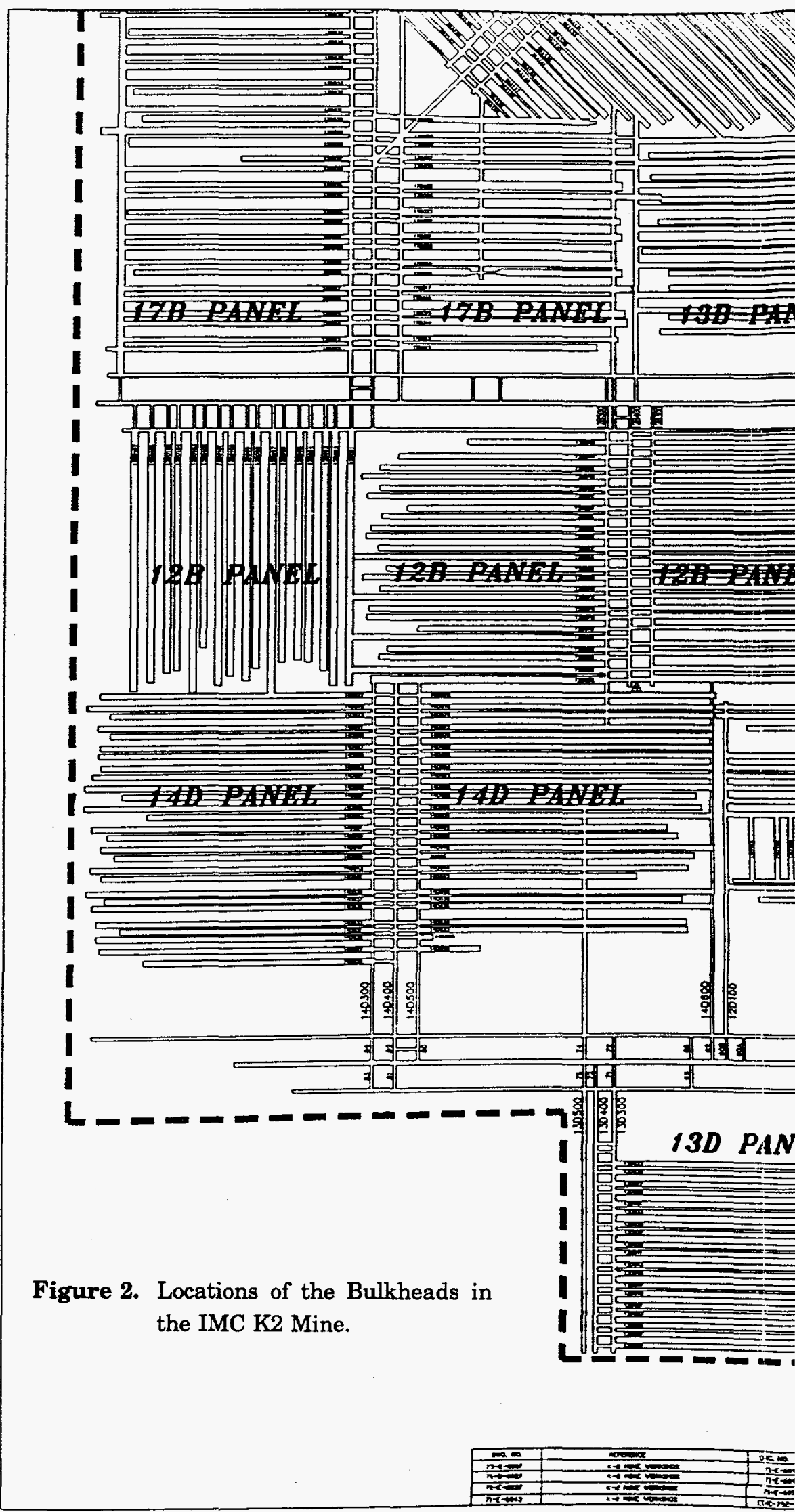




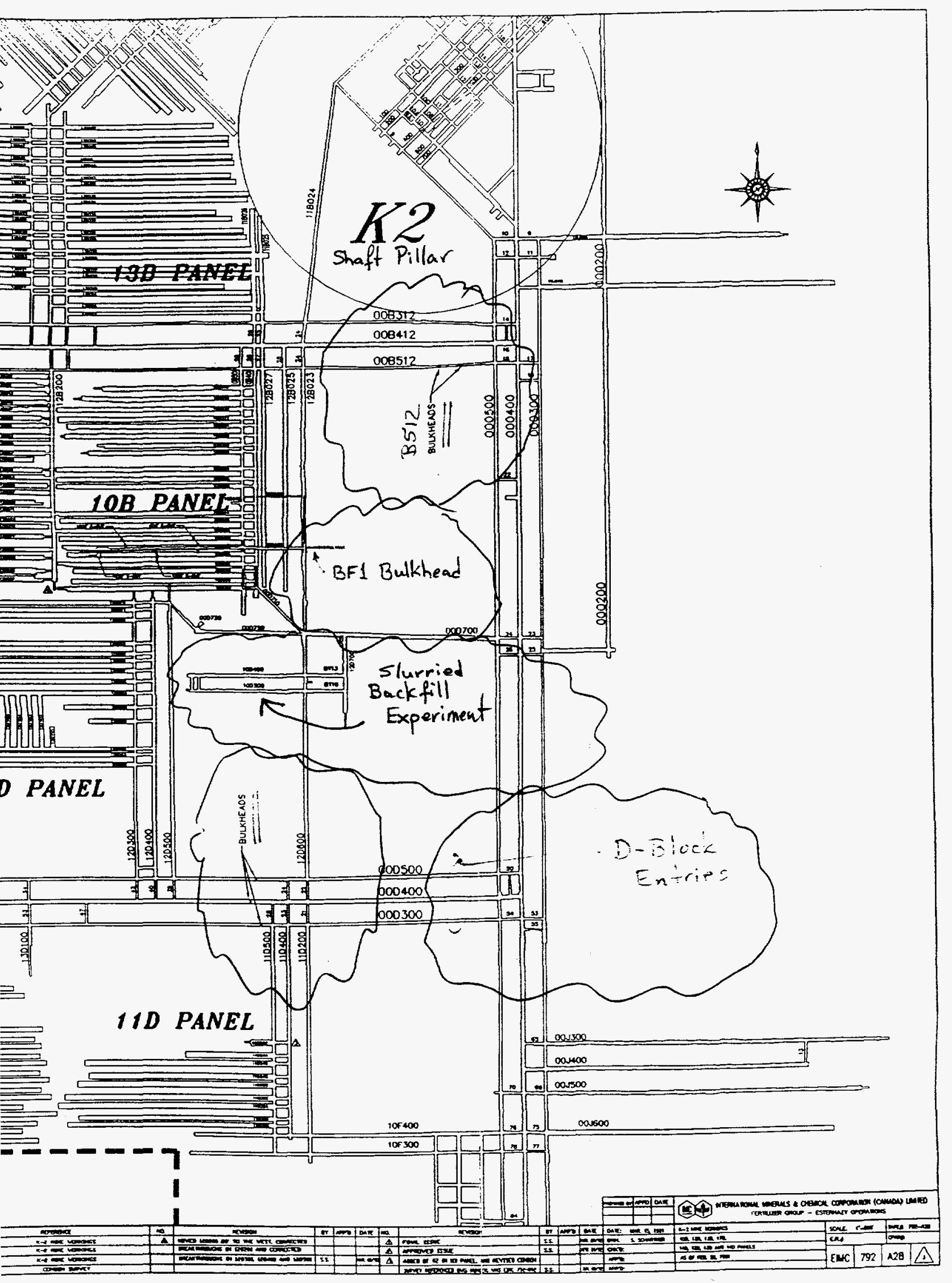




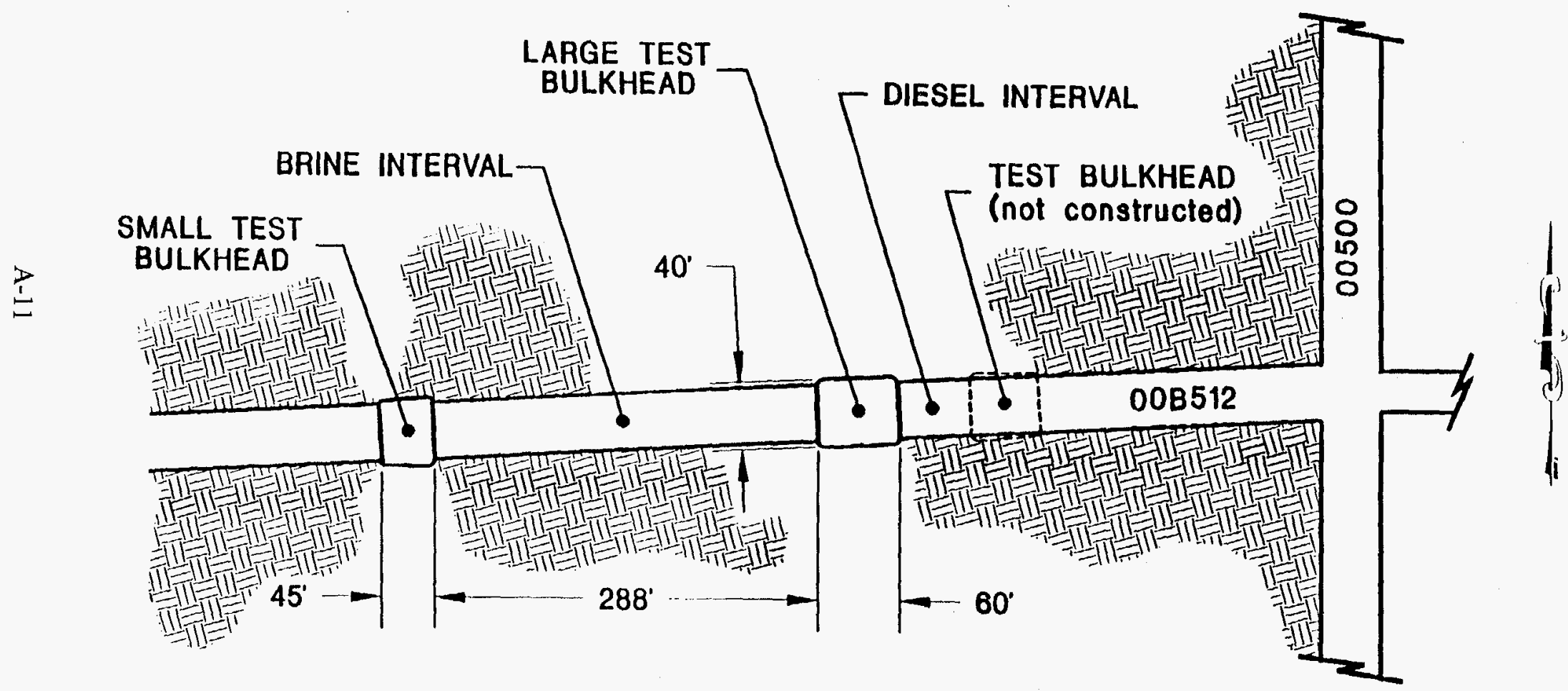

Figure 3. IMC K2 00B512 Test Bulkheads. 
the DRZ. Any loss of the fluid from the interval can be repienished from the accessible side of the upstream concrete dam. The test therefore required three dams: one pair of dams to create an interval for pressurized brine to simulate the flooded mine and another pair to create the interval for the pressurized diesel. The two pair of dams share a common dam of the three dams total. Only one pair of dams was built at IMC: the pair to contain the brine.

The first of the dams was built using a "shotcrete" technique and the second dam was cast in segments using forms. During construction of the first dam, it was realized that the shotcrete method was not working; hence, the change in construction method. The DRZ around the first dam was not removed to the extent it was removed around the second dam. Thus, the construction method and the DRZ both contributed to what proved to be a leaking dam.

\section{CONCRETE}

The concrete used in all the IMC bulkheads was ordinary portiand cement concrete and contained no salt. The D-Block bulkheads were placed quickly for water control. An underground batching plant was used. Cement was batched from regular paper bags. Casting was around the clock. Dust was a problem. Other casting, such as the 512 bulkhead, used FIBCs or supersacks for the cement. Aggregate was charged using a Bobcat tractor and an auger was used to move the cement. The concrete mixture contained 630 pounds of cement, 2,950 pounds of aggregate, and 286 pounds of water per yard. The 28-day strength ranged between 2,140 and 2,650 psi.

\section{FORMING}

The forms were all wood construction. The entire form was erected in place before any concrete was mixed. Then, the form was disassembled and arranged in construction sequence on the drift floor. While the concrete was being placed, control of the lateral force on the form was achieved by allowing the concrete to achieve its initial set before the placement advanced upward. Checks for initial set were accomplished by simply inserting a plunger to feel the depth to the set concrete. If concrete was placed too fast, the set level would be too deep. To avoid overloading the form, concrete placement was slowed. If the set came too close to the surface (and a cold joint couid form), either a set retarder was added or the placement rate increased, depending on the situation.

IMC was originally concerned about finishing the crown to provide intimate contact between concrete and roof salt. They solved this potentially significant problem with a construction feature called EXPANDAMENT HY-RIB ${ }^{i}$, a flexible steel mesh. It was placed at the top of the form construction and allowed the concrete to be pumped against it with pressure. When pumped concrete presses against the EXPANDAMENT, concrete oozes out and the metal fabric

\footnotetext{
: Supplied by Acrow-Richmond LTD., 110 Belfield Road, Rexdale, Ontario M9W 1G1 (416-245-4720).
} 
flexes. This absorbs pressure that would ordinarily be transferred to the wood forms. In this way, it serves as a safety pressure relief valve.

The preemplacement construction of the wood form was necessary primarily to allow cutting of perimeter plywood. The ellipticai shape of the overextended drifts required scuipting pieces to fit around the edges of the forms. Tolerances were typically within an inch of the sait. The remaining cracks were stuffed with buriap and wedged with wood as necessary. Burlap also served dual roles of debonding material (similar to that at Rocanville) and leak prevention. When placed between the plywood face and the concrete, the buriap stopped concrete seepage through small construction cracks. After the forms were stripped, the burlap provided a finish that was rough, and with little preparation such as sand blasting or wire brushing, was well suited for bonding to the next lift face.

\section{GROUTING}

IMC used an effective method for grouting the large concrete bulkhead. A preplaced tube called "injecto-tube" was attached to the back and ribs. These injecto-tubes were porous hoses, wire wound to prevent collapse under the load of green concrete. The injecto-tubes were snaked around the back and ribs, then brought out the front of the forms. After the concrete hardened, the injecto-tubes were injected with cement slurry to high pressure (over 100 psi). This construction technique eliminated worry about evacuation of air pockets and access of the grout to the interface.

\section{CONFERENCE ROOM DISCUSSIONS}

Discussion centered on the B512 bulkhead test. As noted, the test should have comprised three concrete bulkheads. The first bulkhead, called the small bulkhead, provided an outside chamber from which to pressurize the test seal, comprising concrete bulkheads on either end of a diesel-filled chamber. The outside chamber was tested following construction of the first and second bulkheads. The initial pressurization exhibited unacceptable leakage: it leaked like a sieve.

A majority of the leakage was through the small outside plug. The engineers involved in the construction expressed an opinion that the small plug was not in good condition. Its construction was pooriy done. It was shotcreted without the use of forms, except for a vertical block wall to start. This construction method was selected initially because it was felt to be the only method that could close the crown to the back. Insufficient compressed air was available to blow the shotcrete around the room well. To remediate the poor construction, grouting was attempted through angled boreholes to the concrete/salt interface. The suspected poor quality of the shotcrete was substantiated through regularly broken core from these boreholes. Some cementitious grouting was performed, but the records were not immediately available. In anticipation of the performance of the shotcrete, the face of the small plug was tarred before water filling was attempted. Air leakage during water filling showed the plug to leak profusely. 
Access to the small outside piug was not possible on this visit, but could be possible with remediation of access entries $12 \mathrm{~B} 023$ and $00 \mathrm{~B} 512$.

The two large test bulkheads were to be about $60 \mathrm{ft}$ in length, $30 \mathrm{ft}$ in height and $40 \mathrm{ft}$ in width. One test bulkhead was emplaced and is believed to be tight; that is, "no comparison" to the initial small plug. Incidentally, the concrete in single large plug constructed attained a maximal temperature of $65^{\circ} \mathrm{C}$ during hydration. Peak temperature was achieved in the second day following each segment construction. Despite the relatively high temperature, the concrete exhibited no detectable cracking on the surface. IMC used cool water but did not go to heroic efforts to minimize temperature.

Construction of the massive concrete bulkhead did not involve salt-saturation of the concrete. To prevent dissolution of the country sait by the fresh-water concrete, the inside walls, floor, and roof were coated with a sprayed epoxy. The interface was conceptualized to be a slip line. Therefore, the shape of the plug was tapered; the concept was "to push the cork further into the bottle" as lateral pressure is applied.

\section{FOLLOW-UP ACTIVITIES}

A possibility exists to advance the WIPP seals design, evaluation, credibility and compliance through industrial analogues and experience. We consider these initial contacts, not as an end, but potentially as a beginning of a cost-effective relationship that may provide significant dividends to the WIPP seais program. To heip plan future activities, we outline here a few possible follow-on activities.

Messrs. Jim Lewis, PCS, and Martin Reading, IMC, will be sent letters of appreciation for arranging the visits. Our observations and the frank discussions about actual bulkheads (concrete seal components) built under in-the-mine conditions would have been valuable during past design reviews. We can now be more convincing in future statements that concrete structures can be built to specifications without heroic measures and that these concrete monoliths can be hydrologically tight.

Mr. Garth Moore, PCS, will be sent a letter explaining the WIPP seais activities and soliciting available information pending the conclusion of insurance litigation on the Rocanville inflow and dam construction. Of interest are any reports or memoranda that provide details on the design, construction, or rock mechanics/hydrological monitoring of the bulkhead. This request may include the concrete recipe and concrete testing results, rock mechanics and brine pressure data, and as-built drawings.

A request should be made to $\mathrm{Mr}$. Martin Reading for eventual access to the Concrete Technologies Laboratory report (report issued $1 / 22 / 88$ to $\mathrm{Mr}$. Thomas D. Olson, IMC) and the rock mechanics data report for the bulkhead test (probably in John Unrau's possession). A strategy might be explored to develop various levels of testing that could be mutually beneficial and proposed to IMC. Testing could range from a repressurization of the brine interval (which previously leaked like a sieve around the small bulkhead) to coring and in situ testing of the 
large bulkhead. A more extensive (and expensive) effort could invoive rehabilitating old entries to gain access to the small bulkhead and performing a grouting job on that bulkhead before pressurizing the brine interval. Some of these options will be considered in a manner consistent with needs of the seals program and DOE/CAO guidance.

\section{LVS/FDH:krl}




\section{POTASH CORPORATION OF SASKATCHEWAN, INC. ROCANVIIIE DIVISION}

MINE TOUR INFORMATION

\section{HISTORY}

Potash has been a valued commodity since it's first use in early glass, soap, and cloth making industries. Ashes derived from a common Mediterranean plant called Kali or Saltwort, were a source of flux used by Egyptian and Roman glassmakers. Solutions leached from the ash were boiled dry in large iron pots leaving a crude residue known as "potash". Potash has since become a term widely applied to various naturally occurring potassium salts and the commercial products derived from them. More then 908 of the worlds potash production is now used as fertilizer.

Potash deposits were first discovered in Saskatchewan during oil exploration in the early 1940's. The Rocanville mine went into production in september 1970, being the last of ten potash facilities constructed in the province. Since then, over 77 million tons of potash ore have been mined and processed at Rocanville.

\section{GEOLOGY}

Potash ore contains three primary minerals; sylvite ( $\mathrm{KCl}) 33 \%$, Carnaliite ( $\left.\mathrm{KCl} . \mathrm{Mg} \cdot \mathrm{Cl}, 6 \mathrm{H}_{2} \mathrm{O}\right) 78$, and Halite ( $\mathrm{NaCl}$ ) 608 . The ore is located at a depth of 3,145 feet within a potash deposit known as the Esterhazy Member of the Prairie Evaporite Formation. The deposit is Devonian in age (350 - 400 million years old) and was created when an ancient inland sea evaporated leaving a 500 foot thick sequence of salt and anhydrites. The Esterhazy Member is one of four potash members present in this upper portion of the Prairie Evaporites. Only eight feet of the 30 foot thick Esterhazy Member is economical to mine. 
Page ... 2

HEAD FRAMES AND SHAFTS

The mining level is accessed by two 16 foot diameter shafts.

Both shafts, \#1 production shaft and \#2 service shaft, were sunk between the years of 1968 to 1970 . High pressure water formations required freezing, grouting and the installation of permanent water tight cast iron tubbing. The remainder of the shafts are lined with two to three feet of concrete.

\section{Facts on \#1 Production Shaft:}

1. The headframe is 250 feet high.

2. The four headropes are $11 / 2$ " thick.

3. Each skip carries a payload of 27 tons.

4. The skips travel at 3600 FPM.

5. The hoist motor is $6000 \mathrm{H} . \mathrm{P}$.

6. One cycle of the skips takes 104 seconds.

7. Exhaust air route $(250,000 \mathrm{CFM})$.

8. Total depth is 3,340 feet.

\section{Facts on \#2 Service Shaft:}

1. The headframe is 150 feet high.

2. The four headropes are 1 " thick.

3. Nineteen tons of material can be lowered down this shaft.

4. The cage travels at 1,500 FPM (17 MPH).

5. The hoist motor is $600 \mathrm{H} . \mathrm{P}$.

6. One way trip takes just over two minutes.

7. Fresh air route $(250,000 \mathrm{CFM}$ - heated in winter).

8. Total depth is 3,240 feet. 
Page ... 3

MINING

A mining method called long room and pillar is used at Rocanville Division. Most of the rooms (tunnels) are mined 65 feet wide by 8 feet high. A 90 foot wide pillar is left between the rooms to support the overburden above. This results in an extraction ratio of 42 percent.

Room and pillar mining takes place in extraction blocks known as panels. Panels are roughly 5,000 - 6,000 feet square and contain 30 - 40 rooms. Three parallel passes are taken by the mining machine to complete a 65 foot wide room. Each room takes one month to mine and yields approximately 200,000 tons of potash ore. To date there are over 450 miles of extracted entries in the mine.

Potash is mined using large, continuous mining machines called Marietta miners. These miners have been affectionately named after bears because of the claw like rotors on the front of the machine. Rocanville has five of these machines, each one capable of producing 800 tons of potash per hour. The ore is cut by four rotors powered by four $400 \mathrm{H} . \mathrm{P}$. electric motors. The mining machines weigh over 250 tons each and would cost roughly four million dollars today.

When mining first pass, ore from the mining machine is dumped on a 42 inch wide conveyor belt that extends continuously with the miner as the face advances. This conveyor transports the ore at 550 feet per minute to a panel conveyor. The panel conveyor transports the ore up to 6,500 feet out of the panel to a mainline conveyor system. A series of mainline conveyors, each one over a mile long, Carry the ore to a 15,000 ton ore storage bin near the shafts. The potash is automatically reclaimed from the bin, crushed, and loaded into two measuring pockets at number I shaft. Two 27 tons skips operating in counter-balance receive the ore and hoist it to surface.

Ventilation throughout the mine is controlled with brattice seals, doors, and fans. Because of the depth, the air temperature is a constant $78^{\circ}$ fahrenheit. 



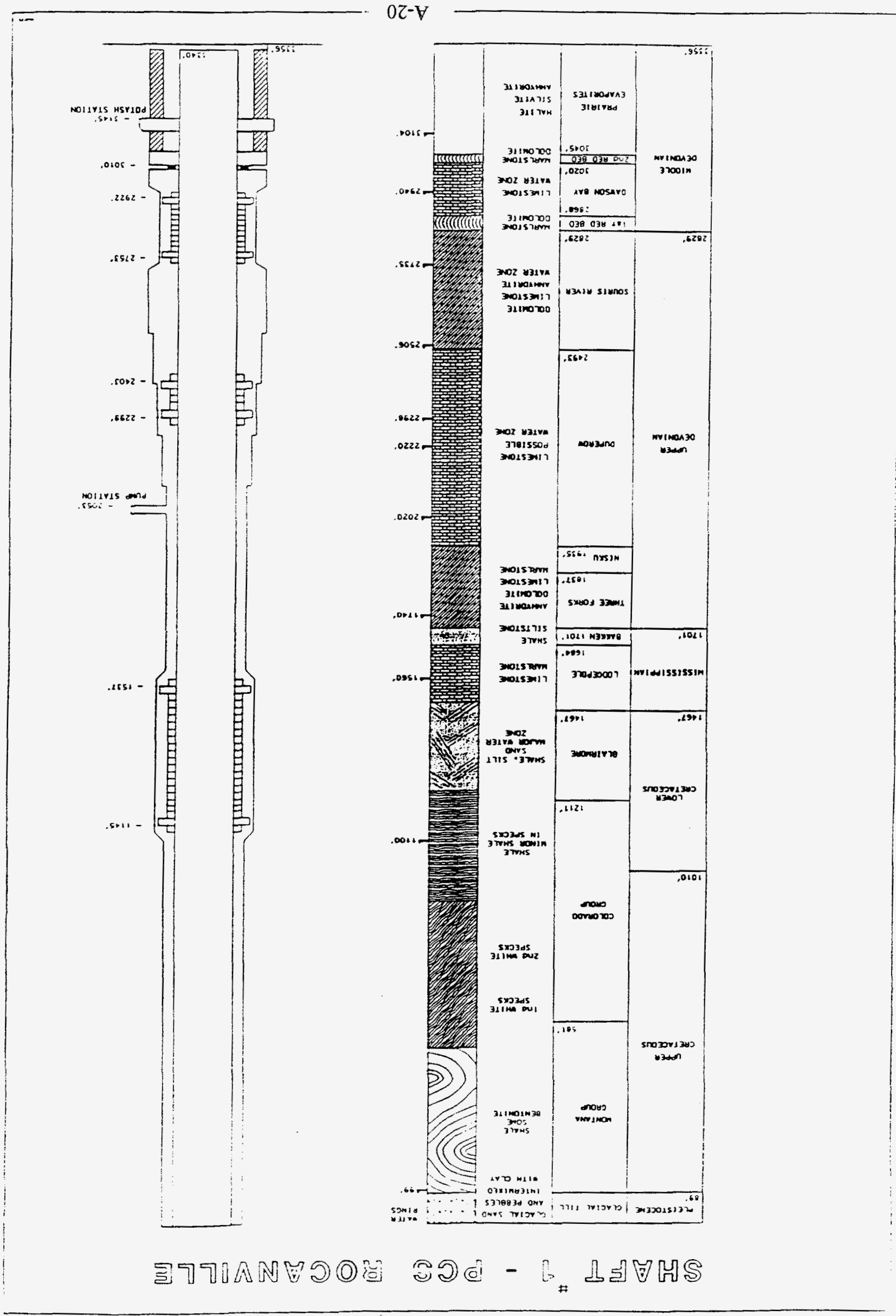




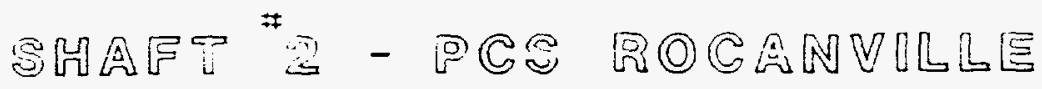
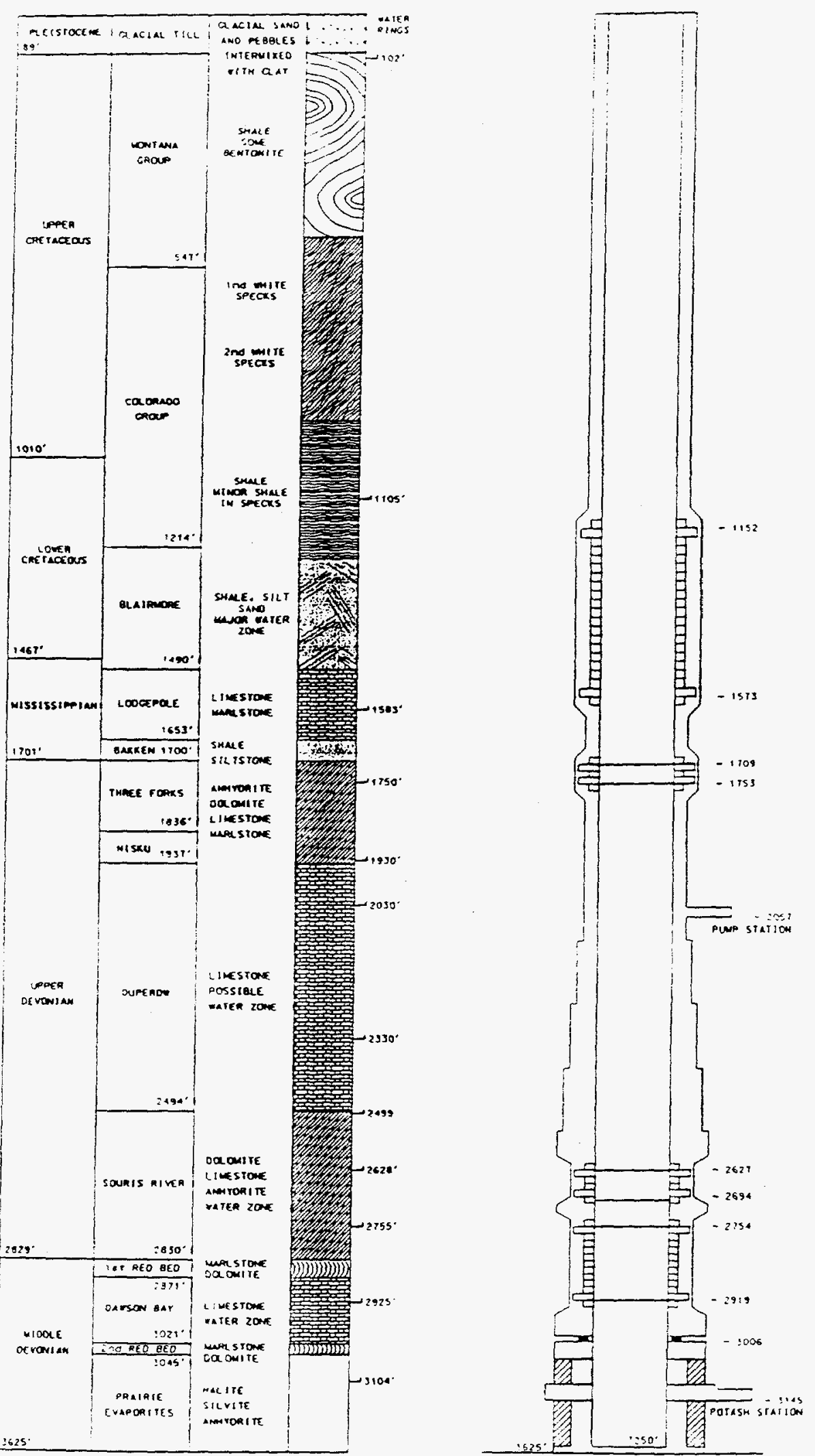


\section{Federal Agencies}

US Department of Energy (6)

Office of Civilian Radioactive Waste Mgmt.

Attn: Deputy Director, RW-2

Associate Director, RW-10/50

Office of Prog. \& Resources Mgmt.

Office of Contract Business Mgmt.

Director, RW-22

Analysis \& Verification Division

Associate Director, RW-30

Office of Systems \& Compliance

Associate Director, RW-40

Office of Storage \& Transportation

Director, RW-4/5

Office of Strategic Planning and

International Programs

Office of External Relations

Forrestal Building

Washington, DC 20585

US Department of Energy

Albuquerque Operations Office

Attn: National Atomic Museum Library

P.O. Box 5400

Albuquerque, NM 87185-5400

US Department of Energy

Research \& Waste Management Division

Attn: Director

P.O. Box E

Oak Ridge, TN 37831

US Department of Energy (5)

Carlsbad Area Office

Attn: G. Dials

D. Galbraith

M. McFadden

R. Lark

J. A. Mewhinney

P.O. Box 3090

Carlsbad, NM 88221-3090

US Department of Energy

Attn: E. Young

Room E-178

GAO/RCED/GTN

Washington, DC 20545
US Department of Energy

Office of Environmental Restoration and

Waste Management

Attn: J. Lytle, EM-30

Forrestal Building

Washington, DC 20585-0002

US Department of Energy (3)

Office of Environmental Restoration and

Waste Management

Attn: M. Frei, EM-34, Trevion II

Washington, DC 20585-0002

US Department of Energy

Office of Environmental Restoration and

Waste Management

Attn: S. Schneider, EM-342, Trevion II

Washington, DC 20585-0002

US Department of Energy (2)

Office of Environment, Safety \& Health

Attn: C. Borgstrom, EH-25

R. Pelletier, EH-231

Washington, DC 20585

US Department of Energy (2)

Idaho Operations Office

Fuel Processing \& Waste Mgmt. Division 785 DOE Place

Idaho Falls, ID 83402

US Environmental Protection Agency (2)

Radiation Protection Programs

Attn: M. Oge

ANR-460

Washington, DC 20460

\section{Boards}

Defense Nuclear Facilities Safety Board

Attn; D. Winters

625 Indiana Ave. NW, Suite 700

Washington, DC 20004

Nuclear Waste Technical Review Board (2)

Attn: Chairman

$$
\text { S. J. S. Parry }
$$

1100 Wilson Blvd., Suite 910

Arlington, VA 22209-2297 


\section{State Agencies}

Attorney General of New Mexico

P.O. Drawer 1508

Santa Fe, NM 87504-1508

Environmental Evaluation Group (3)

Attn: Library

7007 Wyoming NE

Suite F-2

Albuquerque, NM 87109

NM Energy, Minerals, and Natural

Resources Department

Attn: Library

2040 S. Pacheco

Santa Fe, NM 87505

NM Environment Department (3)

Secretary of the Environment

Attn: Mark Weidler

1190 St. Francis Drive

Santa Fe, NM 87503-0968

NM Bureau of Mines \& Mineral Resources

Socorro, NM 87801

NM Environment Department

WIPP Project Site

Attn: P. McCasland

P.O. Box 3090

Carlsbad, NM 88221

\section{Laboratories/Corporations}

Battelle Pacific Northwest Laboratories

Attn: R. E. Westerman, MSIN P8-44

Battelle Blvd.

Richland, WA 99352

INTERA, Inc.

Attn: G. A. Freeze

1650 University Blvd. NE, Suite 300

Albuquerque, NM 87102

INTERA, Inc.

Attn: J. F. Pickens

6850 Austin Center Blvd., Suite 300

Austin, TX 78731
INTERA, Inc.

Attn: W. Stensrud

P.O. Box 2123

Carlsbad, NM 88221

Los Alamos National Laboratory

Attn: B. Erdal, INC-12

P.O. Box 1663

Los Alamos, NM 87544

RE/SPEC, Inc

Attn: Angus Robb

4775 Indian School NE, Suite 300

Albuquerque, NM 87110-3927

RE/SPEC, Inc

Attn: J. L. Ratigan

P.O. Box 725

Rapid City, SD 57709

Southwest Research Institute (2)

Center for Nuclear Waste Regulatory Analysis

Attn: P. K. Nair

6220 Culebra Road

San Antonio, TX 78228-0510

Tech Reps, Inc. (4)

Attn: J. Chapman (2)

T. Peterson (2)

5000 Marble NE, Suite 222

Albuquerque, NM 87110

Westinghouse Electric Corporation (5)

Attn: Library

J. Epstein

J. Lee

B. A. Howard

R. Kehrman

P.O. Box 2078

Carlsbad, NM 88221

S. Cohen \& Associates

Attn: Bill Thurber

1355 Beverly Road

McLean, VA 22101 


\section{National Academy of Sciences, WIPP Panel}

Howard Adler

Oxyrase, Incorporated

7327 Oak Ridge Highway

Knoxville, TN 37931

Ina Alterman

Board of Radioactive Waste Management

GF456

2101 Constitution Ave.

Washington, DC 20418

Rodney C. Ewing

Department of Geology

University of New Mexico

Albuquerque, NM 87131

Charles Fairhurst

Department of Civil and Mineral Engineering

University of Minnesota

500 Pillsbury Dr. SE

Minneapolis, MN 55455-0220

B. John Garrick

PLG Incorporated

4590 MacArthur Blvd., Suite 400

Newport Beach, CA 92660-2027

Leonard F. Konikow

US Geological Survey

431 National Center

Reston, VA 22092

Carl A. Anderson, Director

Board of Radioactive Waste Management

National Research Council

HA 456

2101 Constitution Ave. NW

Washington, DC 20418

Christopher G. Whipple

ICF Kaiser Engineers

1800 Harrison St., 7th Floor

Oakland, CA 94612-3430

John O. Blomeke

720 Clubhouse Way

Knoxville, TN 37909
Sue B. Clark

University of Georgia

Savannah River Ecology Lab

P.O. Drawer E

Aiken, SC 29802

Konrad B. Krauskopf

Department of Geology

Stanford University

Stanford, CA 94305-2115

Della Roy

Pennsylvania State University

217 Materials Research Lab

Hastings Road

University Park, PA 16802

David A. Waite

$\mathrm{CH}_{2} \mathrm{M}$ Hill

P.O. Box 91500

Bellevue, WA 98009-2050

Thomas A. Zordon

Zordan Associates, Inc.

3807 Edinburg Drive

Murrysville, PA 15668

Universities

University of New Mexico

Geology Department

Attn: Library

141 Northrop Hall

Albuquerque, NM 87131

University of Washington

College of Ocean \& Fishery Sciences

Attn: G. R. Heath

583 Henderson Hall, HN-15

Seattle, WA 98195

\section{Libraries}

Thomas Brannigan Library

Attn: D. Dresp

106 W. Hadley St.

Las Cruces, NM 88001

Government Publications Department

Zimmerman Library

University of New Mexico

Albuquerque, NM 87131 
New Mexico Junior College

Pannell Library

Attn: R. Hill

Lovington Highway

Hobbs, NM 88240

New Mexico State Library

Attn: N. McCallan

325 Don Gaspar

Santa Fe, NM 87503

New Mexico Tech

Martin Speere Memorial Library

Campus Street

Socorro, NM 87810

WIPP Public Reading Room

Carlsbad Public Library

$101 \mathrm{~S}$. Halagueno St.

Carlsbad, NM 88220

\section{Foreign Addresses}

Studiecentrum Voor Kernenergie

Centre d'Energie Nucleaire

Attn: A. Bonne

SCK/CEN Boeretang 200

B-2400 Mol, BELGIUM

Atomic Energy of Canada, Ltd.

Whiteshell Laboratories

Attn: B. Goodwin

Pinawa, Manitoba, CANADA R0E ILo

Francois Chenevier (2)

ANDRA

Route de Panorama Robert Schumann

B. P. 38

92266 Fontenay-aux-Roses, Cedex

FRANCE

Claude Sombret

Centre d'Etudes Nucleaires de la Vallee Rhone

CEN/VALRHO

S.D.H.A. B.P. 171

30205 Bagnols-Sur-Ceze, FRANCE

Commissariat a L'Energie Atomique

Attn: D. Alexandre

Centre d'Etudes de Cadarache

13108 Saint Paul Lez Durance Cedex

FRANCE
Bundesanstalt fur Geowissenschaften und

Rohstoffe

Attn: M. Langer

Postfach 510153

D-30631 Hannover, GERMANY

Bundesministerium fur Forschung und

Technologie

Postfach 200706

5300 Bonn 2, GERMANY

Institut fur Tieflagerung

Attn: K. Kuhn

Theodor-Heuss-Strasse 4

D-3300 Braunschweig, GERMANY

Gesellschaft fur Anlagen und Reaktorsicherheit (GRS)

Attn: B. Baltes

Schwertnergasse 1

D-50667 Cologne, GERMANY

Physikalisch-Technische Bundesanstalt

Attn: P. Brenneke

Postfach 3345

D-3300 Braunschweig, GERMANY

Shingo Tashiro

Japan Atomic Energy Research Institute

Tokai-Mura, Ibaraki-Ken, 319-1 1

JAPAN

Netherlands Energy Research Foundation ECN

Attn: L. H. Vons

3 Westerduinweg

P.O. Box 1

1755 ZG Petten

THE NETHERLANDS

Svensk Karnbransleforsorjning $\mathrm{AB}$

Attn: F. Karlsson

Project KBS (Karnbranslesakerhet)

Box 5864

S-102 48 Stockholm

SWEDEN

Nationale Genossenschaft fur die Lagerung

Radioaktiver Abfalle (2)

Attn: S. Vomvoris

P. Zuidema

Hardstrasse 73

CH-5430 Wettingen

SWITZERLAND 
AEA Technology

Attn: J. H. Rees

D5W/29 Culham Laboratory

Abington, Oxfordshire OXI4 3DB

UNITED KINGDOM

AEA Technology

Attn: W. R. Rodwell

044/A31 Winfrith Technical Centre

Dorchester, Dorset DT2 8DH

UNITED KINGDOM

AEA Technology

Attn: J. E. Tinson

B4244 Harwell Laboratory

Didcot, Oxfordshire OX11 ORA

UNITED KINGDOM

D. R. Knowles

British Nuclear Fuels, plc

Risley, Warrington, Cheshire WA3 6AS

1002607 UNITED KINGDOM

\section{Internal}

$\begin{array}{lll}\underline{\text { MS }} & \text { Org. } & \\ 1327 & 1502 & \text { P. J. Hommert } \\ 1320 & 6115 & \text { P. B. Davies } \\ 1328 & 6749 & \text { E. J. Nowak } \\ 1328 & 6741 & \text { D. R. Anderson } \\ 1332 & 6121 & \text { J. R. Tillerson } \\ 1335 & 6705 & \text { M. Chu } \\ 1341 & 6811 & \text { A. L. Stevens } \\ 1341 & 6747 & \text { D. R. Schafer } \\ 1341 & 6748 & \text { J. T. Holmes } \\ 1395 & 6700 & \text { P. Brewer } \\ 1395 & 6800 & \text { L. Shephard } \\ 1395 & 6707 & \text { M. Marietta } \\ 1395 & 6841 & \text { V. H. Slaboszewicz } \\ 1395 & 6121 & \text { F. D. Hansen } \\ 1395 & 6121 & \text { E. H. Ahrens } \\ 1328 & 6749 & \text { D. R. Anderson } \\ & & \\ 1330 & 6752 & \text { C. B. Michaels (2) } \\ 1330 & 6752 & \text { NWM Library (20) } \\ 9018 & 8523-2 & \text { Central Technical Files } \\ 0899 & 4414 & \text { Technical Library (5) } \\ 0619 & 12615 & \text { Print Media } \\ 0100 & 7613-2 & \text { Document Processing (2) } \\ & & \text { for DOE/OSTI }\end{array}$

Distribution - 5 




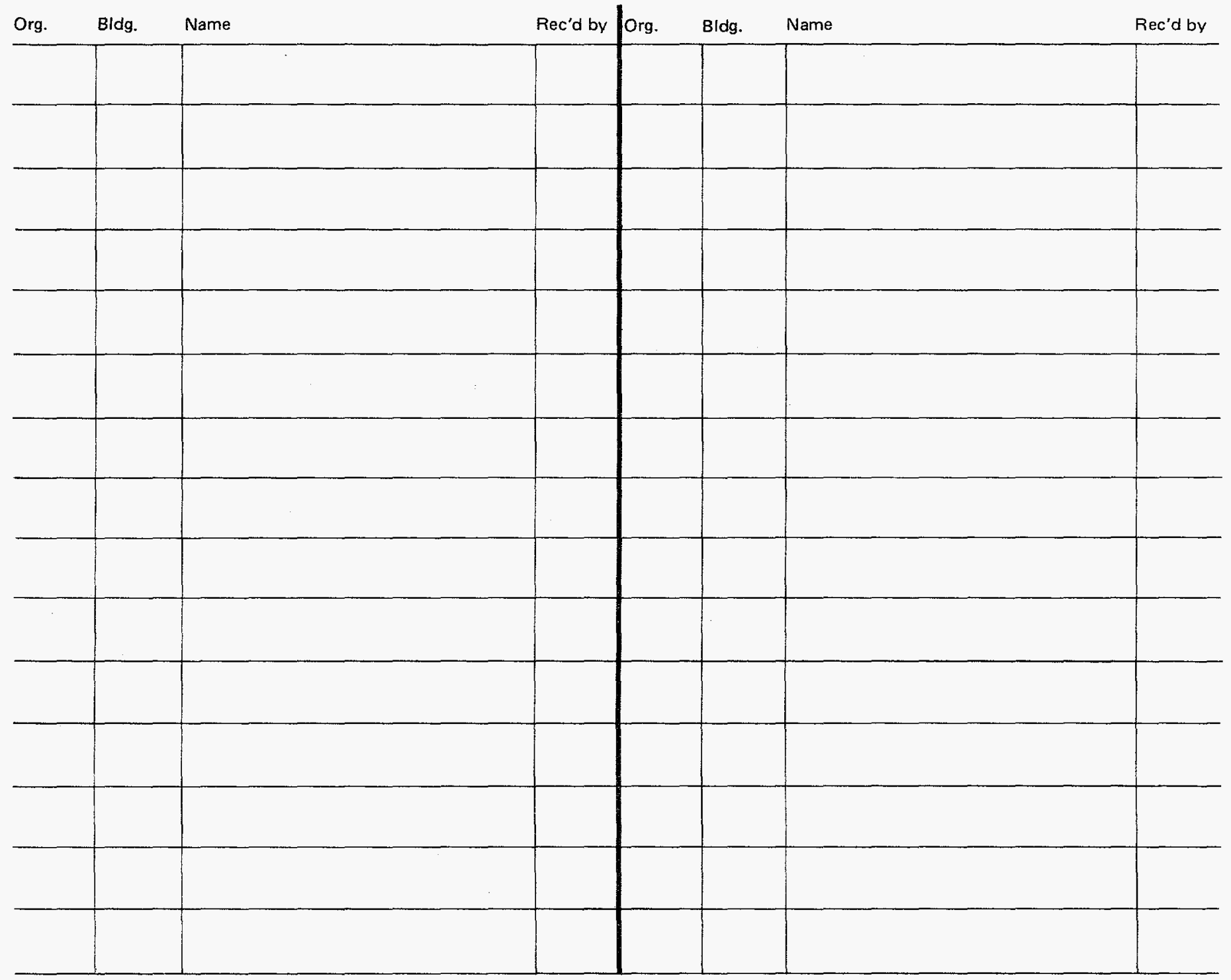

